Historic, Archive Document

Do not assume content reflects current scientific knowledge, policies, or practices. 

a. -148

United States (copy 4$)$ Department of

Agriculture

Forest Service

Intermountain

Research Station

General Technical

Report INT-235

(14.5)
An Annotated Bibliography of the Hydrology and Fishery Studies of the South Fork Salmon River

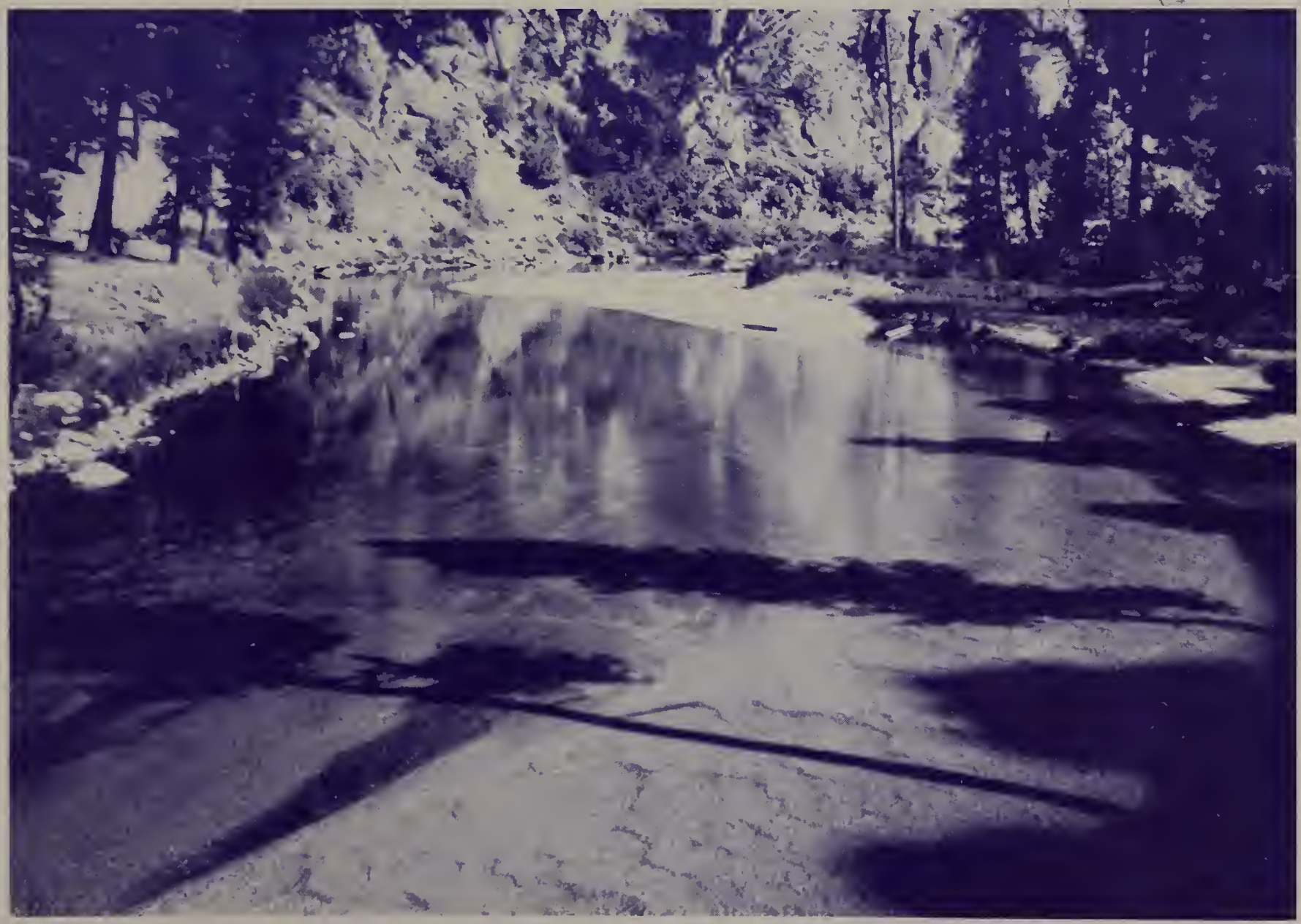




\section{THE COMPILERS}

KATHLEEN A. SEYEDBAGHERI is a hydrologist at the Intermountain Research Station's Forestry Sciences Laboratory in Boise, ID. She attended Boise State University, the University of Notre Dame, and Utah State University, and holds bachelor degrees in anthropology, mathematics, and watershed science. She served as a forestry aide, forestry technician, and hydrologic technician at the Boise laboratory between 1974 and 1980, and has been in her present position since 1980.

MICHAEL L. MCHENRY is a biological technician (fisheries) at the Intermountain Research Station's Forestry Sciences Laboratory in Boise, ID. He earned a B.S. degree in fisheries from Humboldt State University in 1982 and an M.S. degree in fisheries science from New Mexico State University in 1986. He has been employed at the Boise laboratory since 1985.

WILLIAM S. PLATTS is a research fishery biologist at the Intermountain Research Station's Forestry Sciences Laboratory in Boise, ID. He received a B.S. degree in conservation-education in 1955 from Idaho State University, an M.S. degree in fisheries in 1957, and a Ph.D. degree in fisheries in 1972 from Utah State University. From 1957 through 1966, he worked as a regional fishery biologist and supervisor in enforcement with the Idaho Fish and Game Department. From 1966 through 1976, he was the Idaho Zone fishery biologist for the USDA Forest Service, Intermountain Region, and consultant to the Surface Environment and Mining (SEAM) program. He has been in his present position since 1976.

\section{CONTENTS}

Introduction $\ldots$

How To Order Publications .............. 3

Bibliography .................... 3 


\title{
An Annotated Bibliography of the Hydrology and Fishery Studies of the South Fork Salmon River
}

\author{
Compilers: \\ Kathleen A. Seyedbagheri \\ Michael L. McHenry \\ William S. Platts
}

\section{INTRODUCTION}

This publication provides resource managers with an easily accessible, unified reference source concerning hydrology and fishery studies of the South Fork of the Salmon River drainage in central Idaho. Access to the wealth of knowledge gained on the South Fork, one of the most intensely studied forested river basins in the United States, may serve to promote better multiple-use management in the future.

The South Fork of the Salmon River drainage, part of the Columbia River basin, comprises an area of 826,700 acres (fig. 1). The watershed is almost entirely within the Idaho batholith. Approximately a third of the land in the drainage lies within the Boise National Forest and about two-thirds is within the Payette National Forest (USDA FS 1985).

Elevations range from 2,700 to 9,280 feet, with about half of the drainage in the 5,000- to 7,500 -foot class. The area is characterized by steep slopes with overstory vegetation dominated by ponderosa pine (Pinus ponderosa Dougl. ex Laws.) and Douglas-fir (Pseudotsuga menziesii [Mirb.] Franco) at the lower elevations, and lodgepole pine (Pinus contorta var. latifolia Engelm.), grand fir (Abies grandis [Dougl. ex D. Don] Lindl.), Engelmann spruce (Picea engelmannii Parry ex Engelm.), and subalpine fir (Abies lasiocarpa [Hook.] Nutt.) at the higher elevations (USDA FS 1985).

Summers are typically hot and dry, with warm-season precipitation occurring primarily during high-intensity thunderstorms. Winters are characterized by heavy snows and cold temperatures. Long-duration, low-intensity storms are common in fall, winter, and spring. Most of the annual precipitation falls as snow.

The granitic bedrock of the batholith produces shallow, coarse-textured soils that exhibit high erosion rates, especially when exposed or disturbed. Natural sediment production (assuming undisturbed watershed conditions) within the South Fork watershed is estimated at 65,000 tons per year (USDA FS 1985).

The South Fork basin has a wealth of resources involving minerals, recreation, timber, water, forage, wildlife, and fish. Active mining claims currently being administered total 104. The largest cyanide heap leach gold mine in the State of Idaho is operating in the Stibnite area, in the headwaters of the east fork of the South Fork Salmon River. Recreational use is estimated at 456,000 visitordays per year. Approximately 66,000 acres of the Frank Church-River of No Return Wilderness are within the South Fork drainage. An additional 614,461 acres of the South Fork drainage are within inventoried roadless areas. Of the nonwilderness land, 59,515 acres are considered economically and physically suitable for timber harvest, with a long-term sustained yield capacity of $2,954,000$ cubic feet per year.

Annual water yields for the basin average $1,661,000$ acre-feet. Several permit applications have been filed for hydroelectric development. Current grazing is permitted at a level of 6,600 animal unit months per year. The South Fork drainage provides habitat for more than 200 species of birds. Resident large mammals include elk, mule and whitetail deer, black bear, cougar, mountain goat, moose, bighorn sheep, and the endangered Rocky Mountain gray wolf. The South Fork system supports fish populations of resident species, such as trout and char, and anadromous species including salmon and steelhead (USDA FS 1985).

The South Fork is considered particularly crucial as a source of spawning and rearing habitat for the anadromous fish populations. Historically, the South Fork supported Idaho's largest population of summer chinook salmon (Platts and Partridge 1983). The number of returning adults declined from an estimated high of 10,000 fish in the mid-1950's to an estimated low of 250 fish in 1979. The reduction in returning adult salmon led to the closure of a popular and economically important anadromous sport fishery on the South Fork in 1965. Downstream influences of commercial and sport fishing, as well as construction of eight mainstream hydroelectric dams on the Columbia and Snake Rivers, contributed to this decline. However, degradation of habitat conditions in the upriver spawning areas due to land-use activities was also a contributing factor.

Development of the South Fork drainage prior to 1940 included intensive mining and grazing. Mining activities were responsible for significant deposits of sediment and chemicals to the stream system, while uncontrolled grazing contributed to increased sediment loads and degradation of riparian areas. From 1945 to 1965 , intensive logging activities resulted in dense road networks and other sources of accelerated sedimentation (USDA FS 1985). 


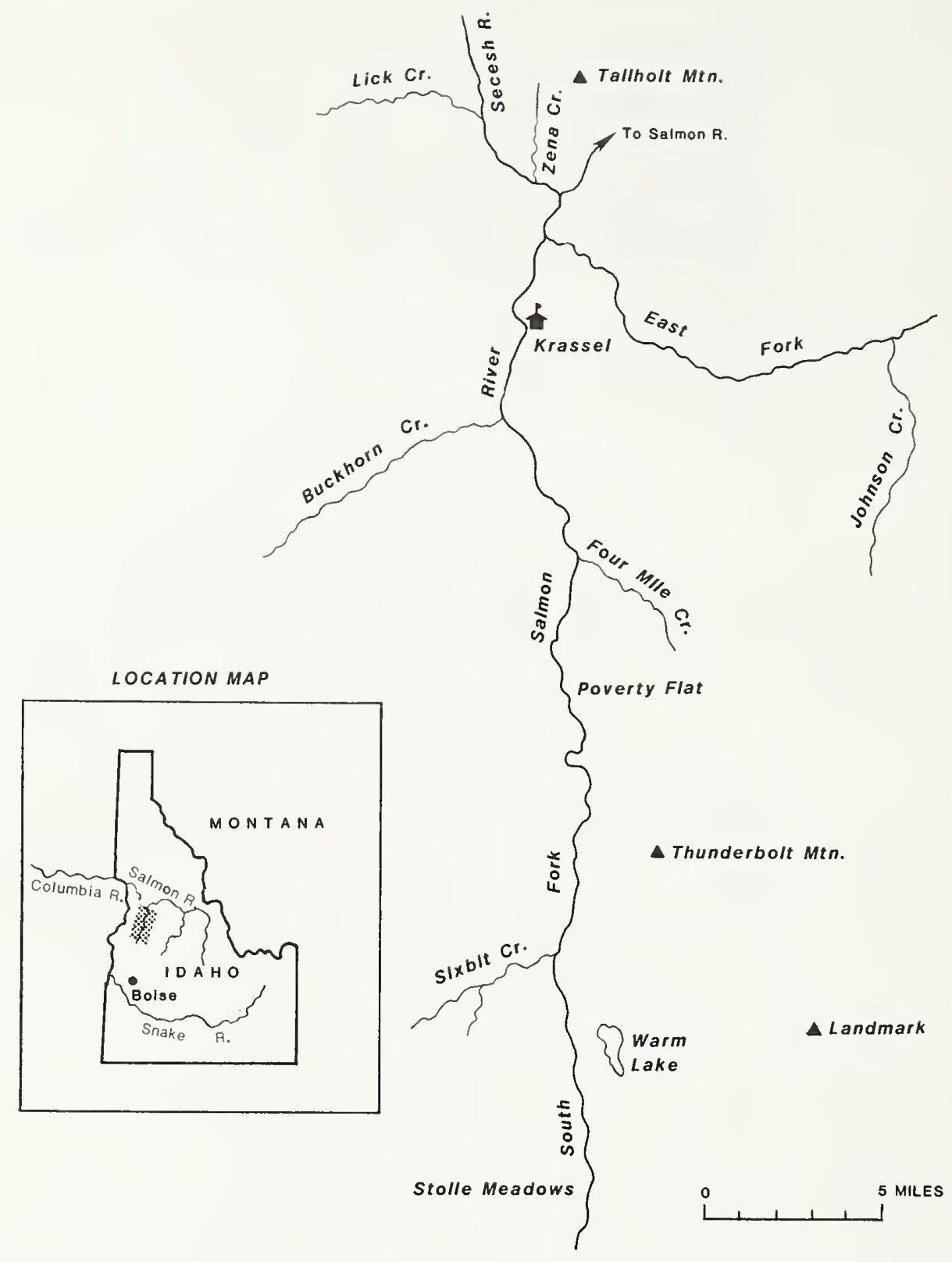

Figure 1-South Fork of the Salmon River. Inset shows the South Fork's placement in Idaho's major river systems.

Extreme climatic events in 1964 and 1965 produced disastrous results for fish habitat. Massive amounts of sediments, up to $1,500,000$ cubic yards annually, were introduced to the stream system (Platts 1970). As sediment production reached its peak historical level (162 percent of natural), anadromous fish production decreased to its lowest level, 20 percent of potential (USDA FS 1985).

In 1965 a moratorium on logging and road construction was imposed in the South Fork Planning Unit. This unit is the largest (348,800 acres) of five major subdivisions of the South Fork drainage basin and contains the majority of the spawning and rearing habitat used by anadromous species in the South Fork system. It includes most of the main stem of the South Fork, plus parts of the east fork of the South Fork and Secesh River drainages. Prior to the moratorium, the unit was heavily developed by logging activities, with approximately 800 miles of roads and an average annual timber harvest of 16 million board feet (USDA FS 1985). A watershed rehabilitation program was implemented in conjunction with the moratorium (Megahan and others 1980).

Research results in the years following the declaration of the moratorium showed a gradual recovery of the fish habitat as indicated by changes in streambed elevation and in average particle size of streambed substrates (Megahan and others 1980). In 1978, a 10-year Land Management Plan was implemented on the South Fork Planning Unit. The plan recognized the anadromous salmonids as the most valuable resource of the unit and conditioned all land disturbance on continued habitat improvement. Manage- 
ment activities (primarily associated with timber harvest) were planned with a constraint that accelerated sedimentation due to the activities could not reverse the improving trend in fishery habitat conditions. Efforts were made to minimize disturbance to soil and streams, reduce erosion on disturbed areas, provide sediment buffer zones, and schedule disturbances so as to disperse the resultant sediment to streams in space and time. Three planning levels placed more specific restrictions on activities to accomplish these goals (Cole and Megahan 1980).

A comprehensive monitoring program was implemented to evaluate the effects of management activities through studies conducted at project sites, in tributary streams, and in the main stem of the South Fork. Timely feedback to land managers regarding existing or potential problems was an integral part of the monitoring process. In addition, the South Fork Salmon River Monitoring Committee, consisting of soil, water, and aquatic specialists from various concerned agencies and organizations, was established to review monitoring results and make recommendations (Cole and Megahan 1980). The early monitoring efforts showed few major impacts from new land-use activities and evidences of habitat improvement (South Fork Salmon River Monitoring Committee 1979, 1980, 1981, 1982 , 1983). However, in 1984, based on the recommendation of the committee, sediment-producing land disturbances were halted temporarily. This was largely due to the failure of some of the spawning areas to show continued improvement (USDA FS 1985). The recommendation was repeated in 1985 and 1986 . No improvement in aquatic habitat was expected under the existing conditions, as the system appeared to be approaching a new equilibrium (South Fork Salmon River Monitoring Committee 1985,1986$)$. Sediment rates were stabilizing at about 113 percent of natural, and anadromous fish habitat was estimated to be 55 percent of potential. A hatchery program, improved downstream fish passage, and other mitigating measures are contributing to increasing fish populations (USDA FS 1985).

\section{HOW TO ORDER PUBLICATIONS}

This bibliography includes annotations of relevant published and unpublished reports on fishery and hydrology studies conducted in the South Fork of the Salmon River drainage. Microfiche copies of all references cited in this bibliography are on file in the library of the Intermountain Research Station. To order, please write to:

Library
Intermountain Research Station
Forest Service
U.S. Department of Agriculture
324 25th Street
Ogden, UT 84401

Orders may also be made by phoning (801) 625-5444.

\section{BIBLIOGRAPHY}

Arnold, John F.; Lundeen, Lloyd J. 1968. South Fork Salmon River special survey, soils and hydrology. Boise, ID: U.S. Department of Agriculture, Forest Service, Boise National Forest. 195 p.
This special study, initiated in 1965 as a cooperative effort between the Forest Service and Idaho Fish and Game Department, evaluates the causes and impacts of recent severe sedimentation on the subject stream. The area surveyed, approximately 254,000 acres, includes all of Cascade Ranger District, Boise National Forest, within the South Fork Salmon River drainage and on the Krassel Ranger District, Payette National Forest, that same drainage, down to the mouth of the east fork of the South Fork, and in addition, the Zena Creek Sale Area and the Secesh River face downstream from Lick Creek.

The report identifies the main sources of sediment production within the South Fork and evaluates the relative amounts of sediment produced in each drainage and its source location. The study area is stratified using the landtype concept as in the Zena Creek Report (Jensen and Finn 1966). Different soils for each mapping unit are identified, and interpretations of the capabilities, potentials, and hazards are made for each unit. Each type and its most important limiting factors are evaluated. Lands are grouped by origin into four categories: strongly glaciated lands, periglaciated lands, stream cut lands, and depositional lands. The South Fork had an annual sediment production of over 92,000 cubic yards with about 22,000 cubic yards of this amount accruing from natural sources. Of the other 70,000 cubic yards, 64,000 are attributed to roads and skid trails. Over 70 percent of the total sediment is produced on the stream cut lands, which make up only 45 percent of the area.

Estimates place the amount of sediment in the channel system at nearly 2 million cubic yards. The river is able to export only about 35,000 cubic yards on an annual basis, so that even if sediment production is reduced to a near natural level, it will take many years for the river to cleanse itself. (Annotation from Skabelund 1970.)

Bethlahmy, Nedavia. 1965. Untitled progress report on 1964 watershed management research, Zena Creek logging study. Unpublished paper on file at: U.S. Department of Agriculture, Forest Service, Intermountain Research Station, Forestry Sciences Laboratory, Boise, ID. $3 \mathrm{p}$.

Based on 2 years of data, Tailholt Creek yields about 1.5 times more water and sediment per unit area than Circle End Creek. Water yields on the two watersheds for water years 1963 and 1964 range from 7.97 to 13.20 inches. Bedload sediment values for roughly the same period range from 71.2 to 130.6 pounds per square mile per day.

Sediment yields for September 1963 to September 1964 from the Deep Creek logging compartment show that on 0.01-acre plots 118 and 122 pounds per acre occurred on the jammer and high-lead areas, respectively. In natural waterways, the measured values are 81 pounds per acre for jammer areas and 12 pounds per acre for high-lead areas. The term "high-lead area" might be deceptive because the logs in that area were removed with high-lead equipment, but were dragged downhill. Analysis of the plot data from May 1962 to September 1964 also confirms the results of a previous study that suggested that runoff and erosion during high-intensity storms were greater on southwest than on northeast slopes (see Bethlahmy 1967; Bethlahmy and Kidd 1964). The data show that the timing 
of erosion processes also differs on the two exposures. Summer-fall erosion rates are greater than winter-spring erosion rates on the southwest aspects, but the rates are fairly uniform for the two periods on the northerly aspects. The data do not indicate any increase in erosion rates associated with logging, aside from that which could be attributed to logging roads.

Bethlahmy, Nedavia. 1967. Effect of exposure and logging on runoff and erosion. Res. Note INT-61. Ogden, UT: U.S. Department of Agriculture, Forest Service, Intermountain Forest and Range Experiment Station. 7 p.

Runoff and erosion from 32 plots in the Zena Creek Logging Sale Area were monitored during 30-minute artificial applications of high-intensity rainfall (average 12.2 $\mathrm{cm} / \mathrm{h}$ ). Plots were chosen to yield equal numbers of northeast and southwest exposures, and of logged and unlogged areas. Average runoff values vary from $0.54 \mathrm{~cm} / 30 \mathrm{~min}$ on logged northeast exposures to $3.72 \mathrm{~cm} / 30 \mathrm{~min}$ on logged southwest exposures. Average sediment yields varied from $2.9 \mathrm{~g} / 30 \mathrm{~min}$ on unlogged northeast exposures to 170.6 g/30 min on logged southwest exposures. Erosion is a logarithmic function of runoff. Runoff and erosion are significantly greater on southwest exposures than on northeast exposures, and significantly greater on logged plots than on unlogged plots for southwest exposures only. Runoff is directly related to percentage of bare soil. Differences in erosion rates are partially explained by differences in slope gradient and in percentage of bare soil. Management implications are included.

Bethlahmy, Nedavia; Kidd, W. Joe, Jr. 1963. 1602 - soil stabilization project. In: Semiannual report, Division of Watershed Management Research, April-September 1963. Unpublished paper on file at: U.S. Department of Agriculture, Forest Service, Intermountain Research Station, Ogden, UT: 9-12 (p. 9-11).

In the Deep Creek logging compartments of the Zena Creek study area, sediment yields following fall 1962 logging were measured using small watershed dams and $1 / 100$-acre plots. In the jammer logging area, the measured value at the dams is 213 tons per square mile for the period from May 28 to July 18, 1963, all attributable to fill slope erosion. In the mobile spar-skyline crane logging area, the corresponding value is 25 tons per square mile and represents skid trail erosion. Sediment yields for roughly the same period from the erosion plots are 7.8 and 17.3 tons per square mile for the jammer and mobile spar-skyline crane areas, respectively. Prior to $\log$ ging, yields from the plots were zero. Data from the unlogged Oompaul Creek compartments for May 28 through September 12, 1963, show no sediment in the small watershed dams, and values of 16.3 and 22.4 tons per square mile for the plots in the jammer and mobile spar-skyline crane areas, respectively. Erosion on the Oompaul plots is attributed primarily to rain splash and gopher activity.

During the 1963 peak flow of March 21 to April 25, average suspended sediment concentrations in Tailholt and Circle End Creeks are 64 and 37 parts per million, respectively. Bedload sediment yields for May 15 to September 4, 1963, are also greater for Tailholt (8.2 tons per square mile) than for Circle End ( 2.2 tons per square mile).
This report contains some tentative results of a study to measure physical and chemical characteristics of road fill slopes. (See Ohlander 1964 for final results of the study.)

Studies of soil moisture in exposed areas at 5,200 feet show that both north- and south-exposure soils dry out beyond their wilting points during the summer. The southern exposure soils become drier than those on northern exposures. Data on percentage moisture at depths of 0 to 2,5 to 7 , and 11 to 13 inches are given for north and south exposures on five measurement dates beginning with June 26, 1963, and ending with September 19, 1963. On June 26, percentage moisture values vary from 9.3 to 20 ; by August 29 all values are below 3. Values of waterholding characteristics at one-third atmosphere (measured at the same depths as given above) vary from 4.4 to 8.1 percent moisture and are consistently higher on the north slopes. For 15 atmospheres the range is 2.2 to 5 percent moisture, with the samples from the northern exposures again having higher values than those from southern exposures at comparable depths.

Preliminary results from an infiltrometer study suggest that runoff is much greater on southwest slopes than on northeast slopes, and also higher on logged southwest slopes than on unlogged southwest slopes. (See Bethlahmy 1967 for the final report on this study.)

Infiltration tests on roads show that, on fully benched roads, runoff is greater from the edge than from the center; however, the rates are similar from edge and center where the road is composed wholly of fill material.

Bethlahmy, N.; Kidd, W. J., Jr. 1964. Zena Creek logging study: progress report - 1963. Highlights of watershed management research activities. Unpublished paper on file at: U.S. Department of Agriculture, Forest Service, Intermountain Research Station, Forestry Sciences Laboratory, Boise, ID. 8 p.

Analyses of 5 years of precipitation data from the Zena Creek study area give the following values of storm characteristics for respective return periods of 1,5 , and 10 years: $2.1,3.5$, and 4.2 inches total rain; 48,72 , and 84 hours duration; 2.5, 4.0, and 4.8 inches per hour maximum intensity (for any interval). All of the values are based on a certainty of 0.5 ; doubling the return period would yield 100 percent reliability. (See Kidd 1964 for the final report on this study.)

Statistical analyses of hydrograph responses to 47 storms occurring between September 1962 and November 1963 show that the variables of time to peak, total rise in stage, and stage on the rising limb are highly correlated on Tailholt and Circle End Creeks. Rising limb stages on the two creeks are described by the relation $T=1.042 \mathrm{C}$ +0.700 (where $T=$ Tailholt stage and $C=$ Circle End stage).

Infiltration measurements on the Oompaul Road demonstrate that the road center is more impervious than the road edge, particularly on cut sections. Nonuniform compaction is the cause.

Studies on forested areas show that both runoff and erosion are much greater on southwest than on northeast exposures. Rainfall of 30 minutes results in an average of 1.3 grams of eroded material per plot on northeast sites, 5.1 grams on unlogged southwest plots, and 88.1 grams on 
logged southwest plots. Values of runoff as a percentage of applied precipitation are 7 for logged northeast, 15 for unlogged northeast, 62 for logged southwest, and 32 for unlogged southwest plots.

Postlogging erosion measurements for May 28 to July 16,1963 , in the small watersheds in the Deep Creek compartments, yield values of 213 and 25 tons per square mile on jammer and mobile spar-skyline crane areas, respectively. Small plot studies give respective values of 7.8 and 17.3 tons per square mile for jammer and mobile sparskyline crane areas. Prelogging erosion values for the small watershed and small plot studies were zero. The skyline crane was used incorrectly by the logger, and so the measured values may be misleading.

Bjornn, T. C. 1971. Abundance of chinook salmon as related to sediment in the South Fork of the Salmon River. Unpublished paper on file at: University of Idaho, Department of Fishery Management, Moscow, ID. Unnumbered pages.

By comparing the abundance of salmon redds since 1951, the author attempts to gauge the effects of massive sediment introductions, associated with poor logging practices and climatological events, to the South Fork Salmon River during the mid-1960's. Although chinook salmon entering the Columbia River system have decreased steadily since the late 1950 's, thus complicating specific analysis of a particular stream, the author presents compelling evidence documenting the decline in abundance of chinook salmon. Because downstream (hydroelectric dams, sport, and commercial fishing) reductions in spawners is assumed as nondiscriminatory toward stocks, comparison of South Fork chinook abundance with those of tributaries not affected by sediment loading will elucidate those effects. Comparisons between redds in the South Fork and those in other less sedimented streams in the drainage indicate the rate of decline in the South Fork proper exceeds the decline in other tributaries in the drainage. The author concludes that the South Fork in its present condition may be able to support the small runs entering the river, but could not provide adequate spawning and rearing areas for the larger runs of past years.

Brusven, M. A.; Gilpin, B. R. 1975. Benthic community dynamics in relation to sedimentary rehabilitation on tributaries of the South Fork of the Salmon River. Ogden, UT: U.S. Department of Agriculture, Forest Service, Intermountain Region. 119 p.

This study provides data on species composition, density, recolonization, and habits of aquatic invertebrates through changing stream habitat before, during, and after watershed rehabilitation in three tributaries of the South Fork Salmon River.

Burns, David C. 1984. An inventory of embeddedness of salmonid habitat in the South Fork Salmon River Drainage, Idaho. Boise and McCall, ID: U.S. Department of Agriculture, Forest Service, Boise and Payette National Forests. 30 p.

The author compares fisheries habitat as measured by substrate embeddedness in "developed" and undeveloped watersheds of the South Fork Salmon River. Developed (roaded and logged) watersheds have significantly higher embeddedness ratings. The highest level of embeddedness was measured in Sugar Creek, immediately downstream from an open-pit mine. The data indicate that a threshold of development exists that, if surpassed, could significantly impact fisheries habitat.

Burns, D. C. 1987. Embeddedness of salmonid habitat of selected streams on the Payette National Forest 19851986. Unpublished report on file at: U.S. Department of Agriculture, Forest Service, Payette National Forest, McCall, ID. 20 p.

This study is a continuation of the author's 1985 work concerning substrate embeddedness levels in the South Fork Salmon River. Four separate areas are analyzed for trends in embeddedness: Thunder Mountain Mining Area, Stibnite Mining Area, South Fork Salmon River, and the Chamberlain Creek drainage. Improving trends are noted in the Stibnite Mining Area and in the South Fork Salmon River drainage. Other areas show little change from 1985 levels.

Burns, David C.; Edwards, Richard E. 1985. Embeddedness of salmonid habitat of selected streams on the Payette National Forest. McCall, ID: U.S. Department of Agriculture, Forest Service, Payette National Forest. $40 \mathrm{p}$.

To better manage the fisheries habitat within the Payette National Forest, substrate embeddedness is evaluated on a number of Forest streams, including seven locations on the main stem South Fork Salmon River.

Clayton, James L.; Larson, Kermit N. 1969. Soil, vegetation and hydrologic survey of Tailholt and Circle End Creeks. Unpublished paper on file at: U.S. Department of Agriculture, Forest Service, Intermountain Research Station, Forestry Sciences Laboratory, Boise, ID. Unnumbered pages.

For 34 mapping units in the Circle End and Tailholt watersheds, the authors evaluate several variables, including general site descriptors, bedrock and soil characteristics, vegetative composition, drainage network attributes, and erosional/depositional features.

They find nine soil series of the Mollisol (now classified as Inceptisol) and Entisol orders. Soil textures include loamy sands, sandy loams, and loamy coarse sands. Soil depths range from 10 to 50 inches. Soil cover by litter and vegetation is generally in excess of 50 percent. Quartz monzonite is the dominant bedrock. Pegmatite, aplite, andesite, granite, and alluvial materials are also represented. Bedrock textures are predominantly mediumgrained. Most of the bedrock is placed in weathering classes 3,4 , and 5 (on a scale from 1 to 7 ). All bedrock fracturing classes are well represented.

Spacing between drainages ranges from 100 to 1,000 feet, while drainage depths (relative to adjacent ridgelines) are 200 feet on the main drainages and up to 30 feet elsewhere. Percentages of each unit undergoing active surface erosion vary from 0 to 100 , with a median value around 80. Erosion is commonly attributed to lack of vegetative cover, steep slopes, game trails, and fire. The authors cite other factors: rodent activity, presence of hiking trails, ice action, local disturbances, concentration of water in 
stream channels, shallow soils, and runoff from rock outcrops. Most units have no significant impediments to sediment delivery to channels, although in a few cases vegetation or rock formations provide barriers.

Clayton, James L.; Megahan, Walter F.; Hampton, Delon. 1979. Soil and bedrock properties: weathering and alteration products and processes in the Idaho batholith. Res. Pap. INT-237. Ogden, UT: U.S. Department of Agriculture, Forest Service, Intermountain Forest and Range Experiment Station. 35 p.

The degree of weathering of batholithic rocks, as described by a previously devised seven-class system, appears to reasonably reflect physical and mineralogic changes in bedrock. The authors observe these changes in hand specimen, thin section, and through chemical, physical, and x-ray analyses of fresh and weathered bedrock from 29 sites in the Idaho batholith, including one at Zena Creek and one at Lick Creek.

After the unloading associated with overburden erosion, initial hydrolysis and oxidation of biotites provide sufficient pathways for water entry, a necessary precursor to physical weathering. Rocks at or near the ground surface then progressively weather to grus, with physical weathering processes dominating chemical weathering. At depth, chemical weathering processes assume greater importance, and the products of chemical weathering are better preserved. Biotites commonly weather to a degraded mica, then to a smectite-iddingsite product, and eventually to a 10-angstrom clay, probably illite. Sericitic weathering products and, ultimately, kaolinization of feldspars are common.

Relationships between soil morphologic properties and bedrock weathering in the Idaho batholith are for the most part obscured by climatic and topographic influences, such as precipitation patterns, slope steepness, and internal soil drainage.

Slope steepness affects erosion rates, and erosion strongly controls the time for pedogenic processes to differentiate soil horizons. Batholith soils are predominantly Entisols, Inceptisols, and weakly developed Alfisols and Mollisols, all reflecting lack of pedogenic development due to high erosion rates. (Adapted from authors' summary.)

Cole, Gene F.; Megahan, Walter F. 1980. South Fork Salmon River-future management. In: Proceedings, symposium on watershed management; 1980 July 21-23; Boise, ID. New York: American Society of Civil Engineers: 396-405. Vol. 1 of 2 vol.

The planned management of the 545 square miles of National Forest System Land in the South Fork Salmon River planning unit includes management directions and environmental policies. These are discussed as related to the goal of maintaining the trend of improvement of the salmon spawning areas.

Corley, Donald R. 1976. Fishery habitat survey of the South Fork Salmon River-1975. Boise, ID: U.S. Department of Agriculture, Forest Service, Boise and Payette National Forests. 70 p.

This report is the first in a series summarizing the fishery habitat condition of the South Fork Salmon River.
The purpose of these reports is to trace the rehabilitative process in a watershed badly damaged by land management activities. The physical structure of the river, streambed substrate composition, and juvenile fish populations are evaluated. Habitat condition is satisfactory for spawning of chinook salmon in the Stolle Meadows area, while high levels of fine sediment are severely impacting the Poverty, Krassel, and Glory spawning areas.

\section{Corley, Donald R.; Burmeister, Lyle A. 1978. Fishery} habitat survey of the South Fork Salmon River-1977. Boise, ID: U.S. Department of Agriculture, Forest Service, Boise and Payette National Forests. 90 p.

This is the second in the series of reports designed to monitor fishery condition of the South Fork Salmon River. Physical rearing areas are improving. Conversely, spawning habitat has improved little, with large volumes of fine sediments continuing to impact downstream spawning areas.

Corley, Donald R.; Burmeister, Lyle A. 1980. Fishery habitat survey of the South Fork Salmon River-1979.

Boise, ID: U.S. Department of Agriculture, Forest Service, Boise and Payette National Forests. 79 p.

This third report in the series indicates that fishery condition continues to be impacted by massive amounts of fine sediment in lower spawning reaches of the South Fork Salmon River. Spawning conditions range from good in the Stolle Meadows area to poor at the Poverty, Oxbow, and Glory areas.

Corley, Donald R.; Newberry, Donald D. 1982. Fishery habitat survey of the South Fork Salmon River-1981. Boise, ID: U.S. Department of Agriculture, Forest Service, Boise and Payette National Forests. 83 p.

The fourth in the series of reports investigates the physical structure, streambed composition, and juvenile fish populations of the South Fork Salmon River. Streambed core samples indicate a continuing trend in fine sediment reduction. Snorkel surveys show juvenile salmon to be a fourth as abundant in 1981 as in 1979. Measurements of rearing pool width and volume, and riffle area vary considerably, indicating a need for improved methodology.

Note: The fifth publication in this series is by Newberry and Corley (1984).

Craddock, George W. 1967. Zena Creek logging study evaluation report. Ogden, UT: U.S. Department of Agriculture, Forest Service, Intermountain Region and Intermountain Forest and Range Experiment Station. $63 \mathrm{p}$.

This report pulls together all of the available information on the Zena Creek logging study (1959 to 1966), to provide an historical account of the progress of the various phases of the study and to evaluate the overall achievement and failures of the study at the termination of the timber sale contract. Included are a background, a brief history of the study, and a review of the initial study objectives and how these objectives evolved during the course of the study. Logging and road construction activities associated with the timber sale are described here in quantitative and qualitative terms. Administrative and 
research studies are outlined, as well as some of the study results. The evaluation summary gives an overview of the ambitious and complex study that encountered many difficulties, but from which much is learned. The administrative and research studies provide a wealth of new information to land managers working in the batholith, but research has not been part of the planning process. The logging operations have experienced considerable difficulties in terms of road failures and shortcomings of the equipment, but efficiency has improved over the years, and mistakes have been recognized and corresponding adjustments made. It has become clear, however, that the logging system used in Zena Creek is not the ultimate answer for logging in the batholith. The author concludes:

The Zena Creek Logging Study as a whole accomplished much toward a better understanding of the timber management possibilities on the steeply sloping lands of the Idaho batholith. The study demonstrated that timber can be harvested economically and without watershed damage on portions of the steeper lands by careful location and construction of logging roads and use of a mobile spar and aerial crane. It also demonstrated that some of the lands having shallow soil derived from decomposed granite are too unstable to withstand the disturbance of road construction. Therefore, unless some aerial cable system can be devised that will permit yarding logs at greater distances and without having to build roads across vulnerable slopes, it appears that some portions of the batholith should not be managed for timber production.

Curtis, James D. 1965. Zena Creek logging study. Progress report-1964. Timber management research. Unpublished report on file at: U.S. Department of Agriculture, Forest Service, Intermountain Research Station, Forestry Sciences Laboratory, Boise, ID. 7 p. (p. 6).

Warm-season (June through September) precipitation totals at 5,000 feet in the Zena Creek area are, in inches, 5.72 in 1959, 2.31 in 1960, 2.62 in 1961, 4.24 in 1962, 7.13 in 1963, and 8.77 in 1964 , with an average value of 5.13 . The 6-year averages by month are, in inches, 2.22 for June, 0.42 for July, 0.91 for August, and 1.58 for September.

Gardner, R. B.; Hartsog, William S.; Dye, Kelly B. 1978. Road design guidelines for the Idaho batholith based on the China Glenn road study. Res. Pap. INT-204. Ogden, UT: U.S. Department of Agriculture, Forest Service, Intermountain Forest and Range Experiment Station. $20 \mathrm{p}$.

This paper is a follow-up to one by Hartsog and Gonsior (1973). Performance of the China Glenn Road, which was designed for minimum environmental impact, is reassessed 6 years after the initial construction and 5 years after the second phase of construction. In the second phase, the road was extended and design criteria refined based on the results of the initial construction. The authors are generally impressed with the performance of the initially constructed portion of the road. Revegetation of cuts and fills is good, drainage features are functioning well, and no slope failures have occurred. For the second phase of construction, the area disturbed is lessened, fewer culverts are installed in minor draws, a modified dip design is implemented, and drainage during construction is allowed for in the design. The authors find that the road is very stable and that the goal of minimum impact has been achieved.

Recommendations are made: Minimize clearing widths and road travel widths. Contour and roll grades in such a manner as to produce minimal disruption of natural drainage patterns and to minimize cut and fill areas. Design turnouts so that the area disturbed is minimized. Construct dips (perpendicular to the center line) during grading to control water during and after construction while minimizing effects on vehicles. Use a variety of drainage control features to regulate flows on roads without ditches. Use slash to help limit sediment movement from fills. Revegetate cuts and fills the first year following construction.

Gonsior, M. J.; Gardner, R. B. 1971. Investigation of slope failures in the Idaho batholith. Res. Pap. INT-97. Ogden, UT: U.S. Department of Agriculture, Forest Service, Intermountain Forest and Range Experiment Station. $34 \mathrm{p}$.

Severe but not unusual climatic events in the winter of 1964 to 1965 and in spring 1965 started a significant number of landslides in the Zena Creek drainage. Although some of the mass movement activity might have been expected under undisturbed conditions, roads are primarily responsible for the accelerated erosion processes. Studies conducted in 1967 use a variety of field and laboratory techniques to describe the soils and assess the causes of failure. Thirteen sites representing fill, cut, and natural hillslope failures, as well as those representing alluvial erosion processes and a stable embańkment, are chosen for intensive study.

Failures are attributed to natural terrain instability, slope steepness (natural and artificial), poor drainage, and minimal fill compaction. Some fills include logs and stumps that contribute to instability. Sonic booms could also have adverse effects on stability.

Recommendations for future construction: Conduct stability analyses of fill slopes, and limit gradients on unretained fills to 70 percent. Build cut slopes as steep as possible, using slope rounding when necessary. Avoid deep fills or cuts or both by sacrificing alignment. Compact fill slopes based on evaluation of their material properties and design standards. Improve drainage to limit pore pressures in fills and cuts, and to limit surface runoff concentrations. Inslope and berm fill sections; check for adequacy of erosion protection on outsloped benched sections. Remove logs and debris from fill material. Revegetate fill slopes in a timely manner with suitable species; place materials at the fill slope toe to limit sediment movement. Stabilize roadbeds. Prevent movement of eroded cut slope material into live streams. Make necessary analyses of soil properties and of surface and subsurface water conditions prior to deciding road locations. Use multidisciplinary teams to minimize impacts on the functioning of the natural systems. 
Hartsog, W. S.; Gonsior, M. J. 1973. Analysis of construction and initial performance of the China Glenn Road, Warren District, Payette National Forest. Gen. Tech. Rep. INT-5. Ogden, UT: U.S. Department of Agriculture, Forest Service, Intermountain Forest and Range Experiment Station. 22 p.

The China Glenn Road was constructed between July and September of 1970 to provide immediate access for a salvage timber sale in the $\mathrm{K}$ Creek, China Creek, and Big Flat Creek watersheds. It is the first new road to be constructed in the area in several years and is designed for minimum impact. Design features include outsloping, 90 -foot minimum radius of curvature, intercepting dips, and riprapped culverts. In addition, the route is placed above the usual danger zone for rain-on-snow events and avoids traversing slopes in excess of 65 percent, while cut and fill slope gradients are limited to 100 and 67 percent, respectively.

Based on observations before and during construction, the authors make several recommendations: (1) Use specialized clearing equipment on steep slopes to alleviate the need for pioneer road construction. (2) Leave slash at fill slope toes to retain sediment whenever practical. (3) Construct fill slopes at angles less than the angle of repose and compact fill material thoroughly. (4) Avoid terracing on cuts and take measures during construction to reduce cutslope erosion. (5) Regulate sediment transport from cut and tread areas and design road surfaces to carry water. (6) Avoid use of dimpled connecting bands on culverts. Do not orient culverts perpendicular to the center line on extremely steep slopes. Take care in bedding of culverts and allow for camber without bending the pipe. In natural channels use backhoes rather than crawler tractors for culvert installation. Do not use saturated material for backfill, and compact properly. (7) Apply stabilization treatments as soon as construction is complete. (If the road will be used immediately, drainage features may need to be altered in the initial construction phase.) (8) Limit road widths, and heights of cuts and fills, sacrificing alignment when necessary and possible. Also limit the area in turnouts and turnarounds. (9) Find methods to accelerate revegetation of cuts and fills. (10) Foster improved communication between engineers and land managers. Provide for flexibility in adjusting construction contracts as desirable changes become apparent onsite.

Haupt, Harold F. 1963. Zena Creek logging study. Progress report - 1962. Watershed management research. Unpublished paper on file at: U.S. Department of Agriculture, Forest Service, Intermountain Research Station, Forestry Sciences Laboratory, Boise, ID. 4 p.

During water year 1962, both winter and summer precipitation were greater than during the preceding several years. Measured streamflow and sediment in Tailholt Creek show increases from the previous year. For example, bedload sediment yield increases from 8.6 to 14.8 tons per square mile, and the maximum instantaneous discharge increases from 1.81 to 2.76 cubic feet per second per square mile. During the summer of 1962, a control for Tailholt Creek was established at Circle End Creek. The
1962 summer bedload sediment yields at Circle End were negligible.

A major series of storms contributed between 7.5 and 10.0 inches of rainfall during 10 days in October. These storms, of low intensity but of long duration, caused severe damage to a newly constructed haul road on the Secesh face. Examination shows that insloping of roads is more effective than outsloping in erosion prevention (see Haupt and others 1963).

Prelogging measurements of sediment yields in headwater drainages without perennial flow show that road construction caused significant yield increases in the Deep Creek logging compartments but not in the Oompaul compartments. Preconstruction yields were zero in both areas. Following construction, yields on the three measured watersheds in the Deep Creek drainage increased to $12,416,8,960$, and 89.6 tons per square mile. The differences in yields are attributed to variability in road standards, especially drainage features.

Haupt, Harold F.; Kidd, Walter J., Jr. 1962. Zena Creek logging study report, 1961. Watershed management research. Unpublished paper on file at: U.S. Department of Agriculture, Forest Service, Intermountain Research Station, Forestry Sciences Laboratory, Boise, ID. 2 p.

Sediment measurements during water year 1961 showed bed and saltation load sediment yields of $8,9.1$, and 13.1 tons per square mile on Tailholt, Hamilton, and Oompaul Creeks, respectively. Suspended loads were negligible during peak runoff. The high bedload rate on Oompaul Creek is attributed to a 1955 rain-on-snow event in which 360 cubic yards of sediment from a land slump were deposited into the stream channel. The sediment had caused temporary ponding, and then was released forcefully into the system that previously had had a stable bottom. Such phenomena are not uncommon in the area.

Haupt, H. F.; Rickard, H. C.; Finn, L. E. 1963. Effect of severe rainstorms on insloped and outsloped roads. Res. Note INT-1. Ogden, UT: U.S. Department of Agriculture, Forest Service, Intermountain Forest and Range Experiment Station. 8 p.

Damages to insloped and outsloped portions of a newly built, secondary logging road in the Zena Creek logging study area are evaluated following a series of longduration, low-intensity storms. The road, built in June 1962 , goes across west and southwest slopes with gradients in excess of 60 percent. Cut slopes are generally 8 to 14 feet high and composed of granite overlain by soils that are very coarse, sandy, and shallow (less than 20 inches in depth). In September 1962, shoulders and fills were seeded, and covered with hay and asphalt binder.

During 10 days in October 1962, the road was impacted by three storms with durations of 8,38 , and 87 hours. Storm intensities did not exceed 0.20 inches per hour for any hour, or 0.48 inches per hour for any 10-minute period. Measured values of total precipitation due to these storms vary from 7.60 to 9.99 inches at rain gauges in the area. This total is unprecedented in over 50 years of record at McCall.

Soils above the road were saturated early in the storm period, and large amounts of subsurface flow were 
generated. In swales, channel flow also occurred. No culvert failures due to plugging were observed. Damage is much greater on outsloped road sections than on insloped sections. Runoff onto the fills of outsloped sections resulted in considerable erosion, slumpage, and sediment movement, with the greatest damage at incurves. Little erosion of road cut and tread occurs on insloped sections, and severe fill damage occurs only at cross-drains and at swales. The authors conclude that

Insloping... is more desirable than outsloping as a measure for preventing erosion. Specifically, the inslope should be designed to lead as much storm runoff as possible away from the long fill on the incurve of the road. Where culverts are to be used in major ravines, they should be located on the original water grade so that they do not discharge on the fill of the incurve but drain into the original channel. Where earthen cross drains are to be used, they should be located to discharge their flows on the outcurve of the road. Below the outcurve the undisturbed side slope will tend to absorb road drainage and retard sediment flows before they reach a ravine or stream.

The Idaho Citizen. 1977. Sediment and salmon on the South Fork. October-November: 24-27.

This article documents the effects of erosion from logging unstable watersheds in the South Fork Salmon River. Sediment levels moving into the river average 70,000 cubic yards greater than in the undisturbed watershed. Although the stream and watershed have initially recovered, the Forest Service plans to log up to 12 million board feet of timber per year. Included are management viewpoints of interested parties, including the Forest Service, Idaho Fish and Game Department, Boise-Cascade Corporation, Idaho Wildlife Federation, and private citizens.

Jensen, Frank R.; Cole, Gene F. 1963. Restoration (Poverty Burn). Unpublished report on file at: U.S. Department of Agriculture, Forest Service, Intermountain Region, Payette National Forest, McCall, ID. 4 p.

This report documents the history of the Poverty Burn and the efforts made to rehabilitate the area and prevent sedimentation into the South Fork Salmon River. It appraises the various treatments as to cost and success. Treatments evaluated are contour trenching, salvage logging, grass seeding, contour tree felling, and check dams. The most successful treatment of burned areas on this type of landscape would be aerial seeding a mixture of perennial and annual grasses and avoiding disturbance of the burned area in general, either by contour trenching or salvage logging (road building) activities. Salvage areas should be studied carefully to determine what portions of the areas can be logged and still meet watershed stability requirements. (Annotation from Skabelund 1970.)

Jensen, Frank R.; Cole, Gene F. 1965. South Fork of the Salmon River storm and flood report. Unpublished report on file at: U.S. Department of Agriculture, Forest Service, Intermountain Region, Payette National Forest, McCall, ID.
Two periods of severe watershed damage occurred during the winter of 1964-65 in the South Fork of the Salmon River drainage. The climatic conditions, damages, impacts, and causes associated with the events of that winter are investigated on the Krassel Ranger District.

The first period of damage is associated with the "Christmas Storm" of December and January. In those months about 11 inches of precipitation fell, mostly as rain, on a snowpack with moisture contents of 3 to 6 inches, which was already melting due to mild weather. About 5 to 6 inches of runoff were generated in a relatively short time. The combined effect of the precipitation and snowmelt is on the order of a 30-year to 40-year event. Damages include more than 400 slumps on undisturbed slopes, about 50 road undercuts, a major "blowout" of the Poverty Burn area, and "blowouts" of about 50 side stream channels. Over 100,000 cubic yards of sediment reached the channels, with 45 percent from the Poverty Burn, 30 percent from stream blowouts, 20 percent from roads, and 5 percent from natural slumps. Impacts to recreation, timber, and big game are relatively minor. The major impacts are to roads (repair costs in excess of $\$ 35,000$ ) and to the fisheries (more than 6 inches of sand covers most of the spawning gravels and many holes are filled with sand). Most of the damage other than that attributed to the Poverty Burn blowout would probably have occurred naturally. Contour trenching and road construction on the Poverty Burn are primarily responsible for the erosion there.

In April, 3.40 inches of precipitation fell, with 1.03 inches in 1 day during the peak snowmelt period. A total of 89 landslides were surveyed. Of these, 77 percent originated on fillslopes. Certain conditions of soil, moisture, physical position, and slope gradient are involved in all the slides. The total volume of sediment from these slides is 277,400 cubic yards, of which 50 percent was deposited into live streams at the time of the survey. This further contributes to the degradation of the fishery resource. Many channels are scoured to bedrock, which will change the hydrology of the area, making it more susceptible to flooding. Cost of road repairs is in excess of $\$ 50,000$; cost of repairs plus stabilization, in excess of $\$ 200,000$. In addition, 100,000 board feet of timber was transported with little chance of salvage. Impacts to recreation and wildlife, aside from those already mentioned, are expected to be minor. The authors attribute most of the April damages to road construction.

The authors recommend extreme caution for future road construction and logging operations and propose some conservative design criteria for roads in the area. They discourage future contour trenching of burned areas and suggest some rehabilitation measures.

Jensen, Frank; Finn, Larry. 1966. Hydrologic analysis of the Zena Creek logging study area. McCall, ID: U.S. Department of Agriculture, Forest Service, Intermountain Region, Payette National Forest. 123 p.

Undertaken in 1966 at the request of the Zena Creek Logging Study Committee, this study evaluates watershed conditions at the termination of the timber sale. The original questions prompting the Zena Creek Logging Study are addressed based on a review of previous research data and a reconnaissance of the area. 
The five major landtypes on the study area are described in terms of their geologic origin, physical characteristics, and multiple-use capabilities. The sedimentation for any given watershed in the area is directly proportional to the mileage of roads in the watershed on the decomposed granitic landtype. Of the total sedimentation due to roads occurring from the time of inception of the Zena Creek study to the time that the hydrologic analysis was made (127,855 cubic yards), 99.2 percent had originated on the decomposed granitic lands, which contain 80 percent of the total road length of 29.04 miles. Most of the sediment from the road system had reached the streams by the time of the hydrologic analysis. The authors recommend that construction of new roads in this landtype be restricted to ridge tops and to slopes less than 45 percent unless artificial stabilization measures are taken. They also recommend that existing roads in the landtype be put to bed wherever possible. Lesser modifications in road construction practices to allow for the special characteristics of the periglacial and river terrace landtypes are also suggested.

The report contains data on precipitation, water yields, and peak flows, and information on damages from the three major storms that occurred during the course of the Zena Creek study. In the unroaded state, only two of the hydrologic types on the study area would yield runoff from a 1.5-inch, 6-hour storm (25-year storm). The authors recommend that all engineering structures be designed to accommodate storm events with a 25-year return period.

Of a total timber resource of 130 million board feet on the study area, 38,454 thousand board feet were removed (with economic gain to the contractor) during the course of the Zena Creek study. There is little evidence of watershed damage due to logging activities other than that which is associated with access roads. The Skagit logging system represents a significant improvement over systems previously used, but is still inadequate for logging on the decomposed granite landtype due to the need for a supporting road system traversing the slopes. The authors recommend that logging systems requiring no roads or roads only on ridge tops be investigated. They question whether any logging should be allowed in areas where regeneration efforts are likely to fail. Successful regeneration has been achieved on the moister areas of some landtypes, but the record is poor on the decomposed granite landtype. Further research on regeneration is urged.

There are no significant watershed impacts due to wildlife use. Big game winter range use has likely been disrupted by the logging activities. The authors strongly recommend that winter range protection be given top priority in the future because it involves a relatively small area but an important resource.

The authors feel strongly that the landtype concept is useful and should be the basis of all future multiple-use planning, resource inventories, and quotas, not just in the study area, but throughout the Krassel Ranger District.

Kidd, W. J., Jr. 1963. Soil erosion control structures on skidtrails. Res. Pap. INT-1. Ogden, UT: U.S. Department of Agriculture, Forest Service, Intermountain Forest and Range Experiment Station. 8 p.
Between 1953 and 1955, erosion control treatments were installed on 105 skidtrails on four timber sale areas in central Idaho (including Martins Creek on the Krassel Ranger District). Three of the study areas are in the granitic materials of the Idaho batholith; one is in the Columbia River basalts. Treatments include slash dams, diagonal log water bars, cross-ditches, and lopped and scattered slash. In 1955, quantitative measurements of effectiveness of the various treatments are made; qualitative measurements are made in 1957. The weather potential for erosion between the time of installation of the treatments and the time of evaluation is moderate.

Greater erosion rates and slower recovery occur on the granitic soils. Trails in ravines have more erosion than those on sidehills. Erosion increases as spacing between structures increases. Optimal spacing recommendations are made based on parent material, slope gradient, and slope position. Log water bars and cross-ditches, which diverted the flow of water, are more effective in erosion control than are the two slash treatments, which only filter sediment and retard the flow of water.

Kidd, W. Joe, Jr. 1964. Probable return periods of rainstorms in central Idaho. Res. Note INT-28. Ogden, UT: U.S. Department of Agriculture, Forest Service, Intermountain Forest and Range Experiment Station. 8 p.

Five years (1959-63) of rainfall data from the Zena Creek sale area are analyzed statistically to yield return periods (at the 50 percent reliability level) for various events. Total rainfall, duration, and maximum intensities for specified periods are analyzed for 229 rainstorms as recorded at seven gauges at elevations ranging from 4,200 to 6,400 feet. Average total annual precipitation is 28.74 inches, of which approximately 45 percent falls as rain each year.

Storms with total rainfalls of $2,3,4,5$, and 6 inches have return periods of about $2,3,8,23$, and 60 years, respectively. Storm durations of $24,48,72,96$, and 120 hours have respective return periods of about $2,3,5,22$, and 105 years. Maximum 15-minute intensities of 1, 2, and 3 inches per hour have return periods of about $0.5,1.6$, and 3.8 years, respectively. Maximum 1- to 15-minute intensities of $1,2,3,4,5$, and 6 inches per hour have corresponding return periods of about $1,1.5,2,5,13$, and 35 years.

The maximum recorded intensity for a 10 -minute period is about 2.7 inches per hour; for a 20 -minute period it is about 1.4 inches per hour. Maximum recorded intensities for periods of 30 minutes or longer are all less than 1 inch per hour. The highest intensity on record is about 6.3 inches per hour for a period of less than 5 minutes.

Plotting of storm duration vs. rainfall shows that storms of $20,40,60,80$, and 100 hours duration have average rainfalls of about $0.8,1.8,2.7,3.7$, and 4.6 inches, respectively. The number of storms in various classes of depth, duration, and intensity are tabulated by month of occurrence. 
Kidd, W. J., Jr.; Haupt, H. F. 1961. Soil erosion and soil stability as affected by harvesting ponderosa pine by different logging methods. Unpublished study plan on file at: U.S. Department of Agriculture, Forest Service, Intermountain Research Station, Forestry Sciences Laboratory, Boise, ID. 16 p. (p. 4-5).

Prelogging measurements of precipitation, sediment, and streamflow in the Zena Creek area were made in 1959 and 1960. Average total precipitation during the first water year of measurement is 29.4 inches, with the highest 5 -minute intensity occurring at a rate of 3 inches per hour. Summer precipitation totaled about 4 inches in 1959 and 6.7 inches in 1960. Sediment measurements in the spring of 1960 on Oompaul, Hamilton, and Tailholt Creeks showed suspended loads during peak flows to be less than $225 \mathrm{p} / \mathrm{m}$. However, springtime bedload rates are appreciable. These vary from 52 to 1,169 pounds per watershed per day (or from 0.10 to 0.74 pounds per acre of watershed per day), and are quite variable on different measurement dates and on different drainages.

Kidd, W. Joe, Jr.; Haupt, Harold F. 1962. Upstream sediment production as influenced by logging method. Unpublished study plan on file at: U.S. Department of Agriculture, Forest Service, Intermountain Research Station, Forestry Sciences Laboratory, Boise, ID. 13 p. (p. 3)

Precipitation measurements were made in the Zena Creek area in 1959, 1960, and 1961. Average total precipitation at 6,400 feet was 29.4 inches during the first water year of measurement, and 29.7 inches during the second. The greatest 5-minute intensity was 3 inches per hour. Warm season (June through September) rains contributed 5.75 inches in 1959, 2.20 inches in 1960, and 2.59 inches in 1961.

Knight, Charles A.; Thompson, Richard A.; Kulesza, Norbert C.; Dean, Edward N. 1974. Soil-hydrologic reconnaissance, Big Creek Ranger District, Payette National Forest. McCall, ID: U.S. Department of Agriculture, Forest Service, Intermountain Region, Payette National Forest. 211 p.

This report uses the same format, and much of the same information, as the reports by similar names for the Krassel Ranger District and the Cascade Ranger District (USDA FS 1969, 1970). It also draws on the South Fork Salmon River Special Survey, Soils and Hydrology Report (Arnold and Lundeen 1968).

The basic unit of the report is the landtype, of which 41 are identified on the District. These are grouped into eight geomorphic categories. Strongly glaciated lands include six landtypes and make up 27.1 percent of the total area; granitic glacial trough lands, nine landtypes and 35.2 percent of the area; volcanic glacial trough lands, one landtype and 1.3 percent of the area; cryoplanated granitic lands, six landtypes and 18.3 percent of the area; fluvial granitic lands, four landtypes and 3.3 percent of the area; fluvial volcanic lands, two landtypes and 1.6 percent of the area; steep granitic canyon slopes, seven landtypes and 6.8 percent of the area; depositional lands, six landtypes and 6.4 percent of the area.
Lundeen, Lloyd J. 1968. South Fork Salmon River special survey - stabilization survey. Unpublished paper on file at: U.S. Department of Agriculture, Forest Service, Intermountain Region, Payette National Forest, McCall, ID. 10 p. plus graphs.

This survey's purpose is to determine more accurately the sediment sources within the same areas included in the South Fork Report by Arnold and Lundeen (1968). Field crews identify and locate most individual sources and make suggested alternatives of treatment for each. Cost estimates for each alternative are made. The data are programmed for computer use, and the various alternatives of treatment are analyzed as to their cost per yard of sediment reduction. The report covers six levels of suggested treatment ranging from very little treatment to maximum reduction attainable, including high cost measures for slump treatment and cut-slope stabilization. Cost estimates range from $\$ 53,700$ to $\$ 15,555,000$.

Plan 5 comes closest to meeting the needs of restoration of the stream within an acceptable time. This alternative requires treatment on most untreated logging roads and skid trails, nearly all of the proposed debris basins, some stream channel improvement, sheep driveway restoration, and treatment of some of the main roads. This plan would reduce the sediment load in the river by 200,000 cubic yards annually. Estimated cost for this program is $\$ 5,165,450$. The rehabilitation program proposed by the Region to the Washington Office (under 1440 memorandum dated May 20, 1969) calls for all items in plan 4, plus stabilization of the Trail Creek Highway and reconstruction and relocation of the South Fork Salmon River Road (674) from Forest Highway 22 to the Payette National Forest boundary. Cost of this proposal is $\$ 4,877,317$. (Annotation from Skabelund 1970.)

Megahan, W. F. 1965. An evaluation of the change in hydrologic function of watersheds due to proposed model road construction and logging and logging road construction on the Zena Creek logging study area Payette National Forest. Unpublished report on file at: U.S. Department of Agriculture, Forest Service, Intermountain Region, Ogden, UT. $45 \mathrm{p}$.

A proposal is made to construct a "model road" in the Zena Creek logging study area. The road would bisect two small drainages and would have a total length of about 1 mile. Logging and logging road construction would also be carried out on these two small watersheds.

Performance criteria are developed for the road. A hydrologic and soils investigation is made to evaluate the needs defined by the five performance criteria that apply to the hydrology of the area. (These define acceptable limits on: drainage discharge into natural channels, sediment deposits in live streams, cut and fill slope stability, road drainage design in terms of return period, and road surface rivulet depths.) Also, the author reviews existing roads through lands similar to those in the vicinity of the model road to see how they reacted in terms of the performance criteria. None of the portions of the existing roads examined meet all five of the performance criteria; in fact, few of them meet any of the criteria. 
Calculations of runoff volume, rate, and sedimentation are made for each of the two watersheds (1) under existing conditions, (2) with the model road, and (3) with logging and logging road construction. Calculations are made for various frequency storms. Without exception, runoff volumes and rates and sedimentation are increased by model road construction and more so by the planned logging operation. Most of the increases are due to road construction. The author feels that the increases due to logging would be erased in 5 to 10 years, while the increases due to road construction would be maintained permanently to some degree.

Although meeting the performance criteria is impossible, recommendations are made for complying with the criteria as closely as possible: (1) Use full bench construction wherever side slopes exceed 60 percent; do not sidecast. (2) Where sidecast is inevitable, or in fill sections, make sure there is an adequate protective strip below the road or provide artificial obstructions to prevent displaced material from entering the main streams as sediment. (3) Use surfacing on the road and road ditch. (4) Prevent air slacking or hold air slack material in place on cut slopes (this will probably require bin-walls). (5) Use mechanical and vegetative stabilization measures on fill slopes. (6) Compact all fills to the maximum to reduce the slump hazard. (7) Provide detention storage structures in the two drainages to precipitate sediment and to reduce flow rates. Be prepared to maintain the storage capacity of these structures. (Adapted from author's summary and conclusions.)

Megahan, Walter F. 1972. Volume weight of reservoir sediment in forested areas. Journal of the Hydraulics Division, Proceedings of the American Society of Civil Engineers. 98 (HY8): 1335-1342.

A total of 90 surface and depth core samples was collected from 12 sediment detention reservoirs in spring 1969 and spring 1970 to evaluate volume weight characteristics. The reservoirs are at the mouths of small watersheds ranging in size from 0.1 to 2.5 square miles; the storage capacities of the reservoirs vary from 30 to 100 cubic yards. Water levels in the reservoirs are regulated by natural flow levels (with the exception of periodic flushing to maintain capacities). Five of the study watersheds (the A, B, C, and Main forks of Tailholt Creek plus Circle End Creek) are in the Zena Creek study area; the others are in the Silver Creek Study Area, which, like Zena Creek, is in the Idaho batholith.

The results of the laboratory analyses of the samples show a wide variation in the volume weights of samples both within and among the various reservoirs, even on the same measurement date. For example, the range of values in the 1969 data is from 8.7 to 103 pounds per cubic foot, and the average is 35.8 pounds per cubic foot. The variation is even greater in 1970 when the average is 67.9 pounds per cubic foot. Thus, it is apparent that the previously used practice of assigning an average volume weight of 90 pounds per cubic foot to all samples is highly inadequate, and that even intensive sampling to determine volume weights is unlikely to yield reliable figures.

An alternative method for estimating volume weights was sought. Various methods using particle size distribu- tions as predictors of volume weight were unsuccessful, partially because of the coarse nature of the sediments in the sample. The best method involves a regression analysis of volume weight versus percentage of organic matter, which yields an $r$-squared value of 0.95 and a standard error of estimate due to regression of 7.3 pounds per cubic foot. Recommendations for future sampling include taking auger core samples on a grid pattern from each reservoir, evaluating organic matter content of the samples, and estimating volume weights from the regression relation. This method is expected to yield more accurate volume weight data, with less effort, than would be obtained by intensive sampling for direct measurements of volume weight.

The author points out that organic sediments may constitute a more significant percentage of total sediment volume weights on forested watersheds than had previously been thought. An average value of 5.1 percent of total sediment weight for the samples in the study is attributed to organic content, and individual sample values are sometimes much higher. Because levels of organic sediments are important determinants of water quality, they should be taken into account when planning land use.

Megahan, W. F. 1974. Erosion over time on severety disturbed granitic soils: a model. Res. Pap. INT-156. Ogden, UT: U.S. Department of Agriculture, Forest Service, Intermountain Forest and Range Experiment Station. 14 p.

A negative exponential equation containing three factors is derived to describe time trends in surface erosion on severely disturbed soils. Data from four studies of surface erosion on roads constructed from granitic materials found in the Idaho batholith (including 1961 to 1967 sediment dam data measuring erosion from road fill, cut, and tread areas in the Deep Creek watershed) are used to develop the equations. The regression of the Deep Creek data (which has an $r$-squared value of 0.98 and a standard error of 502 tons per square mile) indicates a long-term postdisturbance equilibrium erosion rate of 3.5 tons per square mile per day, which matches the value obtained from the Silver Creek road data. The author uses rainfall-intensity data to illustrate that variations in erosion forces, as indexed by rainfall kinetic energy times the maximum 30-minute rainfall intensity (the erodibility index), are not the cause of the time trend in surface erosion. In addition, although vegetative growth can be an important factor in reducing accelerated erosion, it did not cause the rapid erosion decreases found in the cases studied. The evidence suggests that surface "armoring" was the dominant factor causing the time trends in surface erosion. The exponential relationship between time and erosion indicates the need for immediate erosion control measures on newly constructed roads to minimize soil losses during the critical period of the first year or two following construction. (Adapted from author's abstract.)

Megahan, Walter F. 1975. Sedimentation in relation to logging activities in the mountains of central Idaho. In: Present and prospective technology for predicting sediment yields and sources: Proceedings of the sedimentyield workshop; 1972 November 28-30; Oxford, MS. 
Publ. ARS-S-40. Oxford, MS: U.S. Department of Agriculture, Agricultural Research Service, Sedimentation

Laboratory: 74-82.

In the Idaho batholith, early logging activities were concentrated on lands with low erosion hazard. By the mid-1950's, most of these areas of the batholith had been harvested, and loggers moved into areas with higher erosion potential. In 1960, the Forest Service began research on the effects of logging in these areas. These studies fell into three categories: assessment of sedimentation on undisturbed watersheds, quantification of sedimentation due to logging and logging road construction, and evaluation of downstream effects of accelerated sedimentation.

Surveys of sediment detention reservoirs on 14 perennial watersheds (seven in the Zena Creek Study Area and seven in the Silver Creek Study Area) yield reliable estimates of watershed sedimentation due to the dominance of coarse-textured materials that are transported as bedload. In the undisturbed state, average annual sediment yields for these watersheds as measured between 1960 and 1972 range from 4.5 to 26.9 cubic yards per square mile per year. Considerable variation occurs from year to year for each watershed, and the watersheds with the highest sediment yields show the greatest variation. Sediment frequency curves are developed using log Pearson type III frequency analyses for some of the watersheds (including Tailholt Main and Circle End Creeks) having records for 7 years or more.

Included are studies of volume weights of the detention reservoir sediments (see Megahan 1972 for details of this study) and studies on the Deep Creek logging and logging road sediment (see Megahan and Kidd 1972a, 1972b).

Data collected between 1966 and 1971 on the size of surface materials on the bed of the South Fork of the Salmon River show definite time trends following the cessation of logging in 1966. At the Krassel spawning area, sands decrease at a rate of 5.9 percent per year; gravels increase at a rate of 6.2 percent per year. This results in more favorable spawning conditions for the anadromous fish populations. These trends are apparent at the other study sites and are confirmed by studies of channel crosssections and inspection of aerial photos. The trends are attributed to lowered erosion rates on sediment source areas, lack of time for mass erosion hazards to rebuild following the extreme events of 1965 , favorable flow conditions for sediment transport, and lack of extreme climatic events during the recovery period. These conditions allow sediment transport through the system to proceed at a more rapid rate than sediment deposits into the system.

Megahan, Walter F.; Clayton, James L. 1986. Saturated hydraulic conductivities of granitic materials of the Idaho Batholith. Journal of Hydrology. 84: 167-180.

Saturated hydraulic conductivity (Ksat) of granitic bedrock in the Idaho batholith was determined using a borehole pressure testing technique. Tests, conducted at approximately $1.6-\mathrm{m}$ depth increments, range from about 1.6 $\mathrm{m}$ to an average maximum depth of $7.8 \mathrm{~m}$. A total of 58 valid tests were obtained in nine holes at five sites (including one at Lick Creek) in a $145-\mathrm{km}$ long transect line running north-south in the southwest quarter of the batho- lith. Sites represent a wide range in rock fracturing and weathering properties. Seismograph profiles were also run at each test hole. A conditional probability analysis shows that Ksat values are lognormally distributed with a lower bound at zero. Values for Ksat are unrelated to depth, rock matrix porosity, seismic velocity, or rock fracture density. However, Ksat does vary with rock weathering characteristics. Conductivity is lowest in unweathered rock, probably because of restricted fracture apertures. The second least weathered rock class has the highest average Ksat. There is a general decrease in Ksat with increased weathering through the remaining five weathering classes even though rock porosity and fracture density increase with rock weathering. The authors believe that this inverse trend in Ksat with increased weathering is the result of progressively increasing clay formation and mineral expansion that restricts flow in both fractures and the rock matrix. Ksat for bedrock averages an order of magnitude less than Ksat for soil cores, and two orders of magnitude less than Ksat obtained by tracer tests during subsurface flow, making shallow subsurface flow a major hydrologic process at many locations on steep mountain slopes. (Adapted from authors' abstract.)

Megahan, Walter F.; Kidd, Walter J., Jr. 1972a. Effect of logging roads on sediment production rates in the Idaho Batholith. Res. Pap. INT-123. Ogden, UT: U.S. Department of Agriculture, Forest Service, Intermountain Forest and Range Experiment Station. $14 \mathrm{p}$.

Sediment production is monitored for 6 years following jammer road construction in three ephemeral drainages near the head of Deep Creek in the Zena Creek logging study area. The watersheds cover 10 acres, and the roads in the drainages amount to 0.36 miles. Sediment dam data were collected twice each year from November 1960 until September 1967. The road was constructed in October 1961. Following logging in October and November 1962, water bars were installed and the road was seeded with grass.

In the 6 years following construction, surface erosion produced 2,413.5 cubic feet of sediment, and one mass erosion event produced 6,030 cubic feet of sediment, for a total of $8,443.5$ cubic feet. When compared to sediment production on nearby undisturbed watersheds (measured as 0.07 tons per square mile per day), this translates to an increased sediment production of 770 times the undisturbed rate. Surface erosion increased production 220 times; mass erosion, 550 times. A definite time trend is apparent: 84 percent of the total sediment is produced within the first year following construction, and 93 percent within the first 2 years. In the first measurement period following construction (238 days), the sediment production rate is 1,560 times the undisturbed rate. Rates decrease rapidly in subsequent measurement periods, and then fluctuate between 0 and 100 times the undisturbed rate.

The rates are unlikely to ever return permanently to the undisturbed level because of the rapid disintegration of bedrock on the cut and tread portions of the road prism. However, the authors suggest that sediment production rates could be minimized by limiting mileages of roads built; using care in road location, design, construction, and 
maintenance; applying fill stabilization treatments, not limited to seeding, as soon as possible after construction (most of the initial sediment production was from fills); and providing barriers (such as logs and debris) to limit downslope movement of sediment.

Megahan, W. F.; Kidd, W. J., Jr. 1972b. Effects of logging and logging roads on erosion and sediment deposition from steep terrain. Journal of Forestry. 70(3):

136-141.

Erosion and sediment production processes as affected by two logging systems (jammer and skyline) and by road construction are evaluated near the head of Deep Creek in the Zena Creek logging study area. The jammer unit is 21.5 acres; the skyline unit, 22.4 acres. Both were logged in October and November 1962. Study methods include the use of sediment dams in ephemeral channels and $1 / 100$-acre erosion plots.

Erosion plot data, collected between September 1961 and September 1967, isolate the onsite effects of the logging activities, excluding road construction. These data show no significant difference in the rates of erosion due to the two skidding techniques. The erosion rates related to skyline logging might be higher than expected due to use on straight to convex (rather than concave) slopes and the fact that the equipment had been used for downhill (rather than uphill) skidding.

The sediment dam data enable the researchers to evaluate separately the effects of road construction and logging on sediment production. Measurements of erosion rates in the undisturbed condition made in nearby study watersheds yield a value of 0.07 tons per square mile per day. Based on 4.8 years of postlogging sediment dam data, logging alone increases this value by 0.04 tons per square mile per day, or by 0.6 times. Based on 1.35 years of prelogging data and 4.8 years of postlogging data, the increases in sediment production due to roads are 56.2 and 51.0 tons per square mile (of roads) per day, respectively, or an average increase of 750 times the natural erosion rate.

The greatest advantage of the skyline system in terms of erosion reduction is in the less extensive road system required to support it. The use of other logging systems using even fewer roads is judged desirable, and the authors recommend that in the future road location, construction, stabilization, and maintenance be done with greater care.

Megahan, Walter F.; Platts, William S.; Kulesza, Bert.

1980. Riverbed improves over time: South Fork Salmon.

In: Proceedings, symposium on watershed management;

1980 July 21-23; Boise, ID. New York: American Society of Civil Engineers: 380-395. Vol. 1 of 2 vol.

The South Fork of the Salmon River historically supported one of Idaho's largest chinook salmon runs as well as a large run of steelhead trout. From 1950 to 1965, considerable logging and attendant road construction activities took place in the South Fork watershed. A combination of highly erodible soils, steep slopes, widespread soil disturbances from logging and road construction, and some large storm events in 1955, 1962, 1964, and 1965 caused severe sedimentation in the river, filling many of the prime salmon spawning and rearing areas with sand.
The Forest Service responded to the problem by developing a restoration program that included a moratorium on all road construction and logging activities, and a variety of watershed rehabilitation practices. River responses were monitored by photographic documentation, surveys of channel cross sections to document changes in bottom elevation, a series of transects to evaluate the particle-size distribution on the surface of the riverbed in both chinook salmon spawning and rearing areas, and core samples of the channel bottom to determine changes in the particlesize distribution of the channel substrate in spawning areas. Data collected from 1966 to 1979 show statistically significant decreases in bottom elevation and increases in the particle size of bottom materials, indicating an improvement in fish habitat conditions. Improvement is dramatic enough to provide the basis for a cautious reentry into the South Fork watershed for timber harvest purposes beginning in 1978. A second paper (Cole and Megahan 1980) describes how this is to be accomplished. (Adapted from authors' abstract.)

Mickelson, Hal L.; Kulesza, Norbert C.; Stephenson, Clifford R.; Platts, William S. 1973. Review and analysis of the South Fork Salmon River Rehabilitation Program. Boise and McCall, ID: U.S. Department of Agriculture, Forest Service, Boise and Payette National Forests. $357 \mathrm{p}$.

The South Fork Salmon River aquatic environment steadily degraded from 1952 to 1965 because of large (unnatural) accelerated sediment accumulations in the channel system. Investigation in 1966 and 1967 revealed that most of the accelerated sediment originated from roads, skid trails, and "logging only" areas. Except as required to complete existing timber sale contract commitments, logging and road construction activities ceased in 1965. Based upon findings of the South Fork Salmon River Special Survey made from 1966 to 1967 (Arnold and Lundeen 1968), a watershed rehabilitation program was proposed to reduce the volume of accumulated sediments in the river by means of instream sediment traps, and also to reduce the rate of accelerated sediment production by closing and stabilizing logging roads, relocating certain sections of the South Fork Salmon River Road, and stabilizing main roads, skid roads, "logging only" areas, and other lesser sediment-producing areas. Funding for detailed planning and for rehabilitation work was not obtained until 1971. This reanalysis was then made of the problems.

From 1965 to 1971, at least 2 years of favorably high river energies had reduced the volume of sediments in the river by an estimated 40 percent. Natural stabilization of accelerated sediment-source areas had reduced sediment production by an estimated 45 percent. The river will likely continue to flush the excessive sediment accumulations and reach near-natural conditions within the next decade or two without further treatment, assuming no further land disturbance occurs. Natural stabilization processes on sediment source areas can be accelerated by treatment. By reducing the rate of sediment inputs to the river, excessive sediment accumulations may be eliminated allowing the stream to return to natural conditions. Most sediment reduction achieved by 1971 through natural processes 
resulted from the reduction of surface erosion. Before treatment, the potential for mass erosion or mass failure was similar to 1967 . The treatment program that began in 1971 should further reduce both mass erosion and surface erosion potential. Overall, natural stabilization plus treatment will reduce sedimentation rates from accelerated sediment source areas by an estimated 80 percent from 1967 estimated levels. This will provide a comfortable margin of safety to absorb unusually heavy climatic impacts without damage to the river system or the aquatic environment. It will also give the land manager greater leeway in choosing alternatives for management programs in the watershed. The recommended treatment program includes stabilization of logging roads, main roads, the Poverty Burn, and the livestock driveway. It does not include sediment traps, road relocation projects, or treatment of skid roads or "logging only" areas. Skid roads and "logging only" areas have stabilized substantially by natural means since standard treatment for erosion control following logging.

Newberry, Donald D.; Corley, Donald R. 1984. Fishery habitat survey of the South Fork Salmon River-1983. Boise, ID: U.S. Department of Agriculture, Forest Service, Boise and Payette National Forests. 71 p.

For the fifth in a series of reports, the physical habitat, as related to fishery requirements, was monitored in the South Fork Salmon River in 1983. Composition of fine sediments in upper spawning areas fluctuates over the period, without exhibiting any trends, either positively or negatively. However, lower regions of the river improve with respect to fine sediment volume. For example, in 1983 , a 4.3 percent decrease in fine sediments occurred in the Poverty Flats area.

Note: The first four publications in this series are Corley (1976), Corley and Burmeister (1978, 1980), and Corley. and Newberry (1981).

Noble, E. L.; Lundeen, L. J. 1970. Analysis of rehabilitation treatment alternatives for sediment control. In: Proceedings of the symposium on forest land uses and stream environment; 1970 October 19-21; Corvallis, OR. Corvallis, OR: Oregon State University: 86-96.

This study set out to determine the best (most costeffective) method to reduce sediment production resulting from land uses in the South Fork drainage. Researchers use computer analysis of 190 possible treatment alternatives to select superior treatments. To reduce the accelerated sedimentation rate of 63,000 cubic yards annually, treatments costing $\$ 5$ million would have to be implemented. Debris basins prove to be the most effective and economical treatment available.

Ohlander, Coryell Archer. 1964. Effects of rehabilitation treatments on the sediment production of granitic road materials. Fort Collins, CO: Colorado State University. 78 p. M.S. thesis.

Six surface treatments (chipped slash, one layer paper netting, three layers paper netting, asphalt-straw, surface holes, and control) are evaluated for surface erosion control and revegetation enhancement on the fillslope of a new secondary logging road in the Zena Creek study area. The study section of the road is insloped and located on a steep south exposure at 4,500 feet elevation. The road was constructed in June 1962. Study plots were installed and initial soil properties evaluated in August 1962. Treatments (including seeding and fertilization of all plots except the controls) were applied in September 1962. Measurements of sediment and vegetation production as well as of posttreatment soil properties were made in the spring and summer (April through July) of 1963. Climatic analyses show that the study period provides a good indication of the efficiency of the treatments for reducing erosion due to raindrop splash, but provides no test of performance under conditions of surface runoff and little indication of treatment effects on revegetation under conditions of soil moisture deficiency.

Prior to vegetative growth (the treatment stage), the asphalt-straw treatment was most effective in reducing sediment production, and the treatment consisting of one layer of paper netting was the second most effective (with respective sediment production of 242 and 302 pounds per acre). The other methods performed poorly (with sediment production exceeding 10,000 pounds per acre), although the value for the treatment with three layers of paper netting may be artificially high due to the data from one plot. After vegetative growth began, but while the treatments were still playing a major role in erosion control, the same two treatments (but in the opposite order) exhibited the best performances in terms of limiting sediment production (with values of 128 and 138 pounds per acre). After the treatments had become of secondary importance in erosion control, evaluation was made of the production of vegetation on each plot. The same treatments were again judged best. The treatment with one layer of paper netting produced 2,039 pounds of vegetation per acre, while the asphalt-straw treatment had a corresponding value of 1,599 pounds per acre.

The following trends are observed in the soil properties following most of the treatments (although not significantly different between treatments): percentages of silt and clay increase, moisture retention increases, organic matter increases, nitrogen increases in the upper soil levels, cation exchange capacity increases, and upper soil layers become more acidic. Bulk densities, structure, and textural classes do not appear to change in the first year following treatment. There is some variation in soil properties between ridges and swales.

None of the treatments provide significant reductions in slope susceptibility to erosion, but the treatment with one layer of paper netting exhibited the best performance under the somewhat unusual climatic conditions prevailing during the year of the study.

Olson, O. C.; Arnold, J. F. 1960. Soils of the Zena Creek logging study, Payette National Forest. Unpublished paper on file at: U.S. Department of Agriculture, Forest Service, Intermountain Region, Ogden, UT. 29 p. plus maps.

Sixteen soil mapping units are described in the Zena Creek logging study area. Ten of these are composed of single soil taxonomic units; six are composed of two soil taxonomic units. For each of the mapping units, a nontechnical and a more detailed technical description of the soil are presented and erosion hazards assessed. Representative pictures and soil profiles are included for several of 
the units. All of the soils are acidic sandy soils derived from granitic parent materials and have weakly developed profiles. Water movement into and through most of the soils is rapid. The most widespread units are those numbered 2, 8, and 12. These are all grayish sandy soils but differ in average soil depth ( 8 to 16,20 to 40 , and $>40$ inches, respectively), average slope gradient (60 to 75,45 to 60 , and $<40$ percent), water storage (very low, moderate, and high), erodibility (high, moderate, and moderate), and suitability for timber production (low, moderately low, and high).

Ortmann, David W. 1963. Determination of the timing and distribution of adult salmon and steelhead runs. Idaho Fish and Game. 13(154): 92-97.

A temporary counting weir was operated in the South Fork Salmon River during the 1963 chinook run to determine the feasibility of weirs to enumerate anadromous fisheries. Several weir designs were tested and a satisfactory system was selected. The author recommends full monitoring using the preferred weir during the 1964 run.

Ortmann, David W. 1964. Salmon and steelhead harvest and escapement studies, South Fork of the Salmon River. Idaho Fish and Game. 17(1): 1-18.

During the 1964 fishing season, anglers caught 737 steelhead and 1,709 chinook salmon from the South Fork Salmon River drainage. Weir counts indicate 2,895 chinook entered the river. Of the run, 36 percent was harvested, leaving a spawning escapement of about 1,800 fish.

Ortmann, David W. 1965. Salmon and steelhead harvest and escapement studies, South Fork of the Salmon River. Idaho Fish and Game. 17(4): 1-10.

Due to a sport-fishing closure, no chinook harvest estimates were made in 1965 . Weir counts indicate a run of 2,000 chinook adults. Because of high water conditions, less than 100 steelhead were harvested in 1965 on the South Fork Salmon River.

Ortmann, David; Richards, Monte. 1964. Chinook salmon and steelhead sport fisheries in the South and Middle Fork drainages of the Salmon River 1961-1962. Idaho Fish and Game. 14(175): 1-29.

This study represents a continuation and expansion (includes chinook data) of Richards' (1962) initial studies of South Fork Salmon River steelhead runs. Three checking stations collected data on number of angler days, number of fish caught, and stream areas fished. Data are recorded separately for the lower and upper South Fork Salmon, East Fork, Johnson Creek, Lake Creek, and the Secesh River. A total of 4,933 anglers spent 9,879 days harvesting 1,745 chinook. Anglers averaged 0.35 chinook per trip. Calculated harvest is $31.8,29.7$, and 26.1 percent of the South Fork, Johnson Creek, and Secesh River runs, respectively.

Platts, William. 1967. The use of a sediment trap in containing moving bedload materials. Unpublished report on file at: Idaho Department of Fish and Game, Boise, ID. $1 \mathrm{p}$.
During the summer of 1966 , accumulated instream sediment was dredged from the Krassel Hole on the South Fork Salmon River in an attempt to form a barrier to downstream-moving sediment. About 16,000 cubic yards of sediment material were removed at a cost of $\$ 20,000$. High costs make use of this method for stream rehabilitation questionable.

Platts, William S. 1968. South Fork Salmon River, Idaho, aquatic habitat survey with evaluation of sediment accruement, movement, and damages. Unpublished report on file at: U.S. Department of Agriculture, Forest Service, Intermountain Region, Ogden, UT. 135 p.

This report, a companion to the South Fork Salmon Special Survey (Arnold and Lundeen 1968), specifically documents the effect of sedimentation on aquatic habitat and on the fishery resource. Data are from 325 randomly located stream transects and 90 transects on the spawning areas, and from core samples of the streambed. Between 1962 and 1967 sediment increased in the upper 25 miles of the stream by 100 percent. The 1967 studies show a very high sediment content with fine sediments composing 55 percent of the streambed materials on the spawning beds and 50 percent of the streambed surface from its head to the confluence with the Secesh River. This sediment seriously damaged the aquatic habitat by lowering the permeability of the materials in the spawning beds. It also eliminated rearing and overwintering areas, reduced food supplies, and formed blankets of impenetrable sediment over salmonid production areas. Sediment transport was evident during all periods of the year due to the filling of deep pools and a lack of sediment trapping areas. This resulted in movement of sediment onto new redds immediately following the spawning and incubation periods.

At the Krassel Hole, 16,000 cubic yards of sediment were removed from the channel in September 1966. By the following August the hole was filled again. Over 4,000 cubic yards were trapped before high water in May 1967. During that period, additional sediment passed through the hole and continued downstream. This is estimated at 50,000 cubic yards, less that which was trapped. (Annotation from Skabelund 1970.)

A followup progress report is listed under Platts 1972.

Platts, William S. 1969a. The effects of sediment reduction on the fishery resource of the South Fork Salmon River. Unpublished report on file at: U.S. Department of Agriculture, Forest Service, Intermountain Region, Ogden, UT. 4 p. plus 2 tables.

This report, a companion to the economic evaluation report (Platts 1969c), appraises the effects of the proposed restoration program on the fisheries resource. Accelerated sediment has severely impacted the production, rearing, and fishing environments on various sections of the South Fork. Most of this damage has resulted from deposition and scouring of sediments under $9 \mathrm{~mm}$ in size. All three of the environments need improvements to restore the fishery. The author concludes that it would be senseless to attempt to rehabilitate one environment without the others, as each is a limiting factor. Restoration for the Stolle Meadows area would show immediate fishery benefits. Debris basins should be planned to restore rearing and spawning areas simultaneously. 
Platts, William S. 1969b. Lost Creek drainage aquatic habitat as related to past, present, and proposed logging-Payette National Forest. Unpublished report on file at: U.S. Department of Agriculture, Forest Service, Intermountain Region, Ogden, UT. 52 p.

Portions of the Lost Creek watershed had been extensively logged into the late 1960's. One type of logging, clearcutting, then in operation and programmed for future use in the drainage has been well documented in the literature for its potential destructiveness to the aquatic habitat. Logging operations of the type and magnitude programmed for the study area (as of October 1968) could possibly have produced detrimental effects to the aquatic habitat. Direct evidence was lacking, so this report presents indirect evidence supporting this thinking. The author reviews past, present, and predicted future aquatic habitat conditions. (Adapted from author's abstract.)

Platts, William S. 1969c. South Fork Salmon River fishery impact and rehabilitation evaluation. Unpublished report on file at: U.S. Department of Agriculture, Forest Service, Intermountain Region, Ogden, UT. 10 p.

Of the various methods of economic evaluation made on the fishery habitat of the South Fork drainage, the author dicusses which is the most accurate. He says the resident fishery in the late 1960 's is worth about $\$ 22,650$ annually. The anadromous fishery has a value to countries and States other than Idaho.

The value of the anadromous fishery is estimated at $\$ 56,650$, compared to $\$ 432,150$ in the late 1950 's. This reduction has come about largely as a result of downstream dams and deterioration of aquatic habitat; the former is the most important of the two factors. Habitat deterioration is still an important factor.

The author discusses hatchery production of both resident and anadromous fish. Initiation of a hatchery program along with restoration of the river to optimum conditions would produce a fishery value estimated at $\$ 3,365,100$ annually. The author considers estimates in this report to be conservative. They do not include any estimate of the intrinsic values of a fishery. Information from this report is in the May 20,1969, proposal to the Chief for restoration of the South Fork. (Annotation from Skabelund 1970.)

Platts, William S. 1970. The effects of logging and road construction on the aquatic habitat of the South Fork Salmon River, Idaho. In: Western proceedings - 50th annual conference of the Western Association of State Game and Fish Commissioners; 1970 July 13-16; Victoria, BC. Victoria, BC: Western Association of State Game and Fish Commissioners: 182-185.

A major tributary to the Salmon River, the South Fork drainage is characterized by steep mountainous terrain and is composed almost entirely of granitic materials in various stages of decomposition. The South Fork has historically contained Idaho's largest salmon run composed entirely of summer chinook, a species in danger in the Columbia River system. Historically, this run made up about 20 percent of Idaho's total salmon run and 30 percent of Idaho's harvest. It played an important part in both the downriver commercial and the upriver sport fisheries. The drainage was not always plagued by fine sediments. Prior to 1952 , it was in good aquatic habitat condition. This was demonstrated both by field inspection and size of anadromous salmonid runs. From 1962 through 1967 , the streambed surface sediment content $(9.51 \mathrm{~mm}$ and below) increased 100 percent in the upper South Fork (25 miles). From the author's visual observation, as well as streambed surface and depth sampling, it appears this has occurred throughout the South Fork proper. The steelhead trout, salmon, and resident game fish populations have steadily declined from the levels of previous years, resulting in complete or partial closures on segments of the fishery resources. The decline of the summer chinook salmon run into the South Fork Salmon River has caused great concern. (Adapted from author's abstract.)

Platts, William S. 1972. Sediment in a salmon steelhead environment. Ogden, UT: U.S. Department of Agriculture, Forest Service, Intermountain Region; Progress Report II. 106 p.

This is a follow-up study to Platts (1968). The South Fork Salmon River aquatic environment has steadily degraded in quality, due to accelerated sedimentation from disturbed lands. Most of the degradation occurred between 1962 and 1965. Prior to 1952, the drainage was in good aquatic environmental condition. From 1952 to 1965 , the South Fork was incapable of discharging the accrued bedload sediment as fast as it was being recruited. This period corresponded with the increase in logging and road construction activities. The result of these activities caused accrued bedload sediment to overwhelm and destroy much of the drainage's aquatic environment and that of some tributaries. From 1966 to 1971, an equilibrium between sediment import and export within the watershed and within the channel existed. During this period, logging and road construction were suspended because of a logging moratorium. Based on related studies, the accumulation of fines has degraded the South Fork's aquatic environment by lowering the permeability of spawning areas and covering the food-producing riffle areas. Fine sediment also eliminated rearing and overwintering areas and formed blankets of sediment on the surface and within the salmonid spawning areas. (Adapted from author's abstract.)

Platts, William S. 1974a. Chinook salmon runs, fish standing crop and species composition in South Fork Salmon River, Idaho. Ogden, UT: U.S. Department of Agriculture, Forest Service, Intermountain Region; Progress Report 5.48 p.

This report summarizes information regarding the fish populations of the South Fork Salmon River, including both resident and anadromous populations in 38 upper tributaries. Chinook salmon and steelhead trout numbers declined after 1958, as a result of downriver passage problems associated with the development of hydroelectric power in the Columbia River. Resident fisheries also declined after 1964, although this decline is attributed to the influx of massive amounts of fine sediment within the South Fork Salmon River watershed.

Chinook salmon spawn primarily in the main stem of the South Fork, while steelhead prefer tributary streams. 
Survey results indicate that rainbow trout (including steelhead) dominate (50 percent) numbers of fish found in the tributaries. Chinook salmon are second in importance $(25$ percent) and are found primarily in the lower tributaries. Cutthroat trout, brook trout, bull trout, whitefish, and sculpin make up the remainder of species observed.

Analysis of fish populations by landform reveals the following trends: (1) the depositional and fluvial landforms support almost all of the fish, (2) no fish are found in cryoplanated landforms, (3) rainbow trout are the only species found in strongly glaciated landforms, (4) chinook salmon are found mainly in alluvial geomorphic type landforms, and (5) 80 percent of the fish are collected between 3,600 and 5,200 feet elevation.

Platts, William S. 1974b. Geomorphic and aquatic conditions influencing salmonids and stream classification with application to ecosystem classification. Ogden, UT: U.S. Department of Agriculture, Forest Service, Surface Environment and Mining Program, Intermountain Region. 198 p.

Investigations are conducted from July 1970 through September 1972 on 38 streams in the upper South Fork Salmon River. The streams have distinguishing features resulting from the influences of geomorphic processes. Multivariate geomorphic processes generally influence stream condition. Fish populations, in turn, are controlled by aquatic structural characteristics such as depth, width, and elevation of stream channel.

Platts, William S. 1974c. Stream channel sediment conditions in the South Fork Salmon River, Idaho. Ogden, UT: U.S. Department of Agriculture, Forest Service, Intermountain Region; Progress Report 4. 38 p.

Channel substrate composition in the South Fork Salmon River is monitored at seven stations during 1973. Most sites exhibit stable or decreasing trends in percentage of fine sediments, while the percentage of gravel increases. Rubble and boulder composition remains fairly stable, probably because of the depositional characteristics of the area.

Platts, William S. 1979. Relationships among stream order, fish populations, and aquatic geomorphology in an Idaho river drainage. Fisheries. 4(2): 5-9.

This study examines the relation between stream order, fish populations, and geomorphic variables in the South Fork Salmon River. As stream order increases, width and depth increase while percentage of channel containing rubble and gravel and channel gradients decrease. With increasing order, the numbers of chinook salmon, rainbow trout, and sculpin increase, while numbers of bull and cutthroat trout decrease. Fish populations are greatest in stream order 4. Management implications include using stream order as a guide for classification and analysis of fishery populations.

Platts, William S. 1981. Stream inventory garbage inreliable analysis out: only in fairy tales. In: Armantrout, N. B., ed. Acquisition and utilization of aquatic habitat inventory information: Proceedings of a symposium; 1981 October 28-30; Portland, OR. Portland, OR: Western Division, American Fisheries Society: 75-84.
The accuracy or precision of a number of commonly used stream survey measures is evaluated in 13 study sites including the South Fork Salmon River.

Platts, William S.; Martin, Susan B. 1980. Return of the South Fork Salmon. Idaho Wildlife. 2(4): 3-9.

A combination of poor land management and climatological events almost destroyed one of Idaho's most beautiful and productive rivers. But the lesson, bitter as it was, is learned, and the river is making a comeback. The battle isn't over. We have to keep on assisting this river to recovery. (Adapted from article's introduction.)

Platts, William S.; Megahan, Walter F. 1975. Time trends in channel sediment composition in salmon and steelhead spawning areas: South Fork Salmon River, Idaho. On file at: U.S. Department of Agriculture, Forest Service, Intermountain Research Station, Boise, ID. 21 p.

The South Fork Salmon River is an important chinook salmon and steelhead trout fishery in the mountains of central Idaho. Because of increased logging, road construction, and severe floods after 1950, excessive sediment, especially fines, was deposited in the river channel, seriously damaging the major spawning areas by 1966 . A study using a network of closely spaced stream channel cross sections evaluates the riverbed surface materials by size in four major spawning areas in the upper half of the river. The size composition of materials favorable for spawning improved greatly from 1966 to 1974; a large decrease in fines was accompanied by a large increase in gravels and a lesser increase in rubble. The change in spawning materials results from a reversal of the previous high rate of sediment flow into the channel system compared to sediment flow out of the system. The reductions in watershed erosion and sediment entry into the river result from (1) a moratorium on logging and road construction activities on the watershed, (2) natural watershed stabilization processes, and (3) a watershed rehabilitation program. This study demonstrates that logging and road construction on high-erosion-hazard lands such as those in the South Fork Salmon River watershed must be carefully planned and programmed over both time and space to avoid degradation of salmonid spawning areas.

Platts, William S.; Partridge, Fred E. 1978. Rearing of chinook salmon in tributaries of the South Fork Salmon River, Idaho. Res. Pap. INT-205. Ogden, UT: U.S. Department of Agriculture, Forest Service, Intermountain Forest and Range Experiment Station. 11 p.

Fish populations in 23 tributaries of the South Fork Salmon River were sampled in 1971, 1972, and 1974. Juvenile chinook salmon were found in one secondary and 11 primary tributaries. The first $400-\mathrm{m}$ reach of tributary stream adjacent to the South Fork was the most important area for rearing, and supported 58 percent of the total tributary chinook salmon population. Only three tributaries have chinook salmon more than $1.6 \mathrm{~km}$ from the river. The tributary chinook salmon density ranges from 0.01 to $0.38 / \mathrm{m}^{2}$ and averages $0.06 / \mathrm{m}^{2}$ for all streams.

Chinook salmon are rearing with rainbow trout and sculpin over most of their tributary range and occasionally with brook trout, Dolly Varden, mountain whitefish, mountain suckers, and dace. Cutthroat trout and chinook 
salmon are not found together. Chinook salmon prefer the larger, lower gradient, grassy-banked streams that have deep pools. Chinook salmon are found in the fluvial and depositional landtype associations, but mainly in the alluvial and alluvial fan landtypes. (Adapted from authors' research summary.)

Platts, William S.; Partridge, Fred E. 1983. Inventory of salmon, steelhead trout, and bull trout: South Fork Salmon River, Idaho. Res. Note INT-324. Ogden, UT: U.S. Department of Agriculture, Forest Service, Intermountain Forest and Range Experiment Station. 9 p.

Aquatic habitats and their respective fish populations were studied in the South Fork Salmon River during the summer of 1977. From the Warm Lake Bridge to the headwaters, the channel consists of 74 percent riffle and 26 percent pool, with surface substrate of 21 percent boulder, 40 percent rubble, 24 percent gravel, and 15 percent fine sediment. Below the Warm Lake bridge to the confluence of the Secesh River, the channel consists of 55 percent riffle and 45 percent pool, with surface substrate of 32 percent boulder, 35 percent rubble, 16 percent gravel, and 17 percent fine sediment. Juvenile chinook salmon and rainbow-steelhead trout are found throughout the river, except in the upper 5 miles, where only bull trout are found. The river reach in the Stolle Meadows contains the highest densities of fish, with juvenile chinook salmon and sculpin the most numerous. Chinook salmon and rainbow steelhead trout densities are lower than reported in most other Idaho streams having anadromous fishes. Of the habitat attributes measured, only stream width shows any correlation with fish populations. As stream width increases in the river reach above the Warm Lake bridge, bull trout numbers decrease. (Adapted from authors' abstract.)

Platts, William S.; Penton, Vance E. 1980. A new freezing technique for sampling salmonid redds. Res. Pap.

INT-248. Ogden, UT: U.S. Department of Agriculture, Forest Service, Intermountain Forest and Range Experiment Station. 22 p.

A new multiprobe freeze method for determining salmonid redd sediment particle size distribution will collect salmonid eggs and alevins in the redd at any stage of development, any air or water temperature, any stream depth, and will determine their horizontal and vertical location. This method will improve our understanding of embryo and alevin survival rates and causes of their mortality.

The freeze-core method differs from the past freeze methods that expand $\mathrm{CO}_{2}$ liquid to atmospheric pressure. This method expands $\mathrm{CO}_{2}$ to a pressure of $78 \mathrm{psi}$, which provides a higher heat transfer, cooling efficiency, and fewer clogging problems. One field test shows the ratio of $\mathrm{CO}_{2}$ consumed to redd materials lifted as $0.34 \mathrm{lb} \mathrm{CO}_{2}$ per $1 \mathrm{lb}$ of redd material. The paper contains description of the methodology with a listing of parts, materials, and suppliers. (Adapted from authors' research summary.)

Platts, William S.; Shirazi, Mostafa A.; Lewis, Donald H. 1979. Sediment particle sizes used by salmon for spawning with methods for evaluation. EPA-600/3-79-043. Corvallis, OR: U.S. Environmental Protection Agency, Environmental Research Laboratory. $33 \mathrm{p}$.
Researchers determine the size composition of substrates used by chinook salmon for spawning in the South Fork Salmon River, the main Salmon River, and tributaries of the Middle Fork Salmon River. Substrates used by resident trout are analyzed for streams in the Boise and Payette River drainages. These analyses are made spatially to determine particle sizes preferred by spawning salmon, yearly differences in sizes used by these salmon, the size differences used by spring and summer chinook salmon, and differences between channel sediments used by chinook salmon for spawning and those substrates occupied by trout.

The authors present the use of the geometric mean particle diameter method as a companion measurement to "percent fines" for a more complete analysis of sediments used for spawning. The geometric mean particle diameter is more adaptive to statistical analysis than the more common method of using percent fines. The geometric mean diameter of the sediment particle size distribution is used for analyzing channel sediments. The relationship is established between the geometric mean particle diameter and percent fines substrate permeability, and substrate porosity. The strongest correlation between the two methods of analysis, percent fines and geometric mean diameter, is for fine sediments below 0.88 inches in particle size.

Chinook salmon select sediments for spawning that are mainly between 0.28 and 0.79 inches in geometric mean particle diameter, regardless of stream selected. This is a narrow range considering that the mean particle diameters for streambed sediments available for chinook salmon to spawn in vary from less than 0.02 inches to well over 3.94 inches. The composition of spawning sediments selected by chinook salmon each year between 1966 and 1976 was quite uniform. Sediments used in spawning in the South Fork Salmon River decrease in particle size in a downstream direction. Geometric mean diameters 35 miles below the headwaters averaged 0.35 inches; particles 10 miles below the headwaters averaged 0.58 inches. (Adapted from authors' abstract.)

Primbs, Edward R. J.; Platts, William S. 1976. The colonization of the South Fork of the Salmon River by the Columbia sculpin (Cottus hubbsi). Journal of the Idaho Academy of Science. 12(1): 47-49.

During September 1975, fish populations were sampled at two sites on the South Fork Salmon River. At one site only bull trout (Salvelinus confluentus) were collected. At the other site rainbow/steelhead trout (Salmo gairdneri), chinook salmon (Oncorhynchus tshawytscha), and the Columbia sculpin (Cottus hubbsi) were found. The South Fork is one of Idaho's few remaining spawning and nursery grounds for chinook salmon and steelhead trout. Studies show that the sculpin is a predator of salmonid fry and a serious competitor with salmonid fingerlings for stream territory. The senior author suggests that the presence of the Columbia sculpin in the South Fork could be detrimental to Idaho's anadromous fish.

Richards, Monte. 1960. The chinook salmon sport fishery of the South Fork Salmon River drainage. Idaho Fish and Game. 9(19): 1-36.

The author details harvest data on the major portion of the South Fork Salmon River chinook fishery for 1960. 
Richards, Monte. 1962. The steelhead sport fishery of the South Fork Salmon River drainage, 1960-1961. Idaho

Fish and Game. 9(121): 1-34.

At the time of this study, the relative size of this fishery was unknown. The study presents a realistic picture of the South Fork drainage (includes South Fork Salmon, East Fork South Fork Salmon, Johnson Creek, and Secesh River) steelhead fishery, through angler surveys and creek census.

Richards, Monte. 1963. Management of the chinook salmon fishery of the South Fork Salmon River drainage. Idaho Wildlife Review. July-August: 3-7.

This article describes management of the fishery from the standpoint of the Idaho Fish and Game Department and presents harvest, spawning success, and escapement data for 1958 to 1962 . Significant increases in fishing pressure, due to ready accessibility from Boise, will lead to future limitations of harvest.

Skabelund, Paul H. 1970. [Untitled annotated bibliography concerning the South Fork Salmon River drainage.] Unpublished paper on file at: U.S. Department of Agriculture, Forest Service, Intermountain Region, Payette National Forest, McCall, ID. 12 p.

A chronological listing of reports dealing with "the resources and impacts of use thereon within the South Fork Salmon River Drainage" was prepared at the request of the Payette National Forest Supervisor. The author cites and annotates 19 reports written between 1960 and 1970.

South Fork Salmon River Monitoring Committee. 1979. Proceedings of the committee meeting; 1979 March 16; Boise, ID. Unpublished report on file at: U.S. Department of Agriculture, Forest Service, Intermountain Research Station, Forestry Sciences Laboratory, Boise, ID. $25 \mathrm{p}$.

This committee's assigned task was to coordinate research and monitoring efforts in the South Fork Salmon River. The committee's report covers the history of land use planning in the area since 1966 and time trends in sedimentation in response to development activities that began in the 1940 's. In the 1960 's, sedimentation increased beyond the ability of the river to discharge the additional loads. Suspension of land disturbances in 1966 and a rehabilitation program decreased new sediment deposits to the river and allowed removal of the accumulated sediments to begin. A graph of estimated sediment production from surface erosion on temporary logging roads between 1948 and 1974 shows the peak value occurring in 1961 (about 35,000 cubic yards) with secondary peaks in 1965 and 1958 (about 27,000 and 25,000 cubic yards, respectively), and a consistent decrease between 1965 and 1974 (the 1974 value is about 5,000 cubic yards). The numbers of returning adult summer chinook salmon and steelhead trout entering the South Fork undergo a steady decline from 1962 to the formation of the committee.

Plans for future logging, road construction, and mining include associated monitoring efforts. Natural erosion and sedimentation processes should be monitored as well. A summary cites past and ongoing research studies of erosion, sedimentation, streamflow, soil stabilization, channel characteristics, and aquatic habitat. Discussion of the fisheries habitat monitoring of the South Fork by the Boise National Forest (see Corley 1976 and Corley and Burmeister 1978 for results) includes existing and planned stream monitoring programs and fisheries studies.

Streamflow records of the U.S. Geological Survey show that the flood of December 1964, which caused a great deal of damage in the South Fork, was not limited to the South Fork. Record flows occurred throughout many areas of Idaho and in other Western States. The recurrence interval is on the order of 100 to 200 years. This and similar floods caused extensive damage even in some undisturbed areas, so it is difficult to assess the relative contributions of natural and accelerated erosion.

South Fork Salmon River Monitoring Committee. 1980. Proceedings of the committee meeting; 1979 December 12; Boise, ID. Unpublished report on file at: U.S. Department of Agriculture, Forest Service, Intermountain Research Station, Forestry Sciences Laboratory, Boise, ID. 22 p.

At the time of the meeting, the only monitored activity that introduces any significant sediment into the South Fork is construction work at the hatchery satellite facility project during the summer of 1979. It results in temporary exceedances of the Idaho State turbidity standards, but work stoppages are not required. A few other isolated incidents produced impacts in excess of those predicted. In those cases, modifications and mitigations were effective in controlling downstream impacts. Monitoring of sedimentation from natural events and from past management activities is being done to separate these impacts from impacts of the new land-use activities.

Heavy metal analyses of samples from four locations on the South Fork in the Cascade Ranger District show no significant abnormalities. Water quality samples collected at three sites on the South Fork in the Payette National Forest exhibit no change in water quality between 1976 and 1979. Cross-section measurements indicate that large amounts of sediment have been removed from 1966 to 1971, with little change from 1972 to 1973 . In 1979, one site had significant aggradation, but all others had degraded to some degree. Aerial photographs of the South Fork show flushing of sediment from 1965 to 1972.

The chinook salmon run on the South Fork in 1979 is the lowest on record, which may be due in part to the drought. However, studies show that survival is high in years following drought. The committee members believe that the number of returning adults, rather than the lack of suitable habitat, is the limiting factor at the time, but that the existing habitat has to be protected nonetheless. (See Corley and Burmeister [1980] for results of the 1979 habitat monitoring.) Studies indicate that immediately after spawning, the redds in the South Fork were in good shape. Some changes in the percentages of the various bottom material size classes had occurred since 1967 and were particularly pronounced from 1967 through 1972.

The committee members agree that the South Fork is in a stable or slightly improving condition (due to the tight 
controls on land-use activities) and could withstand a severe climatic event without major damage.

South Fork Salmon River Monitoring Committee. 1981. Proceedings of the committee meeting; 1981 January 29; Boise, ID. Unpublished report on file at: U.S. Department of Agriculture, Forest Service, Intermountain Research Station, Forestry Sciences Laboratory, Boise, ID. 4 unnumbered pages plus appendixes.

Results of monitoring activities are as follows (some published data included elsewhere in this bibliography will not be covered here): Six reaches of the South Fork show an overall decrease in fines and an increase in gravel and rubble since monitoring began in 1966.

Analysis of data collected by the U.S. Geological Survey at its stream gauge near Krassel Ranger Station shows a decrease in average streambed elevation of 0.37 feet from 1968 to 1979 , or an average yearly decrease of 0.03 feet.

A summer chinook trapping operation near Cabin Creek trapped 380 fish (194 adults and 186 jacks). Of the adults, 38 percent had tags, indicating that they were involved in a 1978 hatchery release with an apparent return rate of 0.1 percent. The number of tagged jacks ( 29 percent of those trapped) indicates a return rate of 0.04 percent from a 1979 release.

Water quality monitoring at three sites (on the Secesh, South Fork, and East Fork South Fork) within the Payette National Forest shows no major changes in water quality from 1979 to 1980 . Monitoring of 24 cross-sections of the South Fork in the Boise and Payette National Forests shows little change between 1979 and 1980 .

Monitoring for 2 years on the Habitat Improvement Timber Sale near Camp Creek (the first timber sale on the South Fork planning unit since the moratorium) shows no major erosion problems and good revegetation. The South Fork Road Rehabilitation Program, implemented in 1979, significantly reduced potential surface and mass erosion hazards. Road reconstruction for the Teapot Timber Sale was done with minimal sediment delivery. The only problems involve flushing of channel sediment deposits during culvert replacement. Climatic stresses in the South Fork watershed were light to moderate between 1978 and 1980 , and no significant adverse impacts due to management activities are noted during that period.

Macroinvertebrate populations sampled in 1980 exhibit a good balance among trophic groups, which is indicative of good water quality and habitat conditions.

Core samples collected in 1980 from six spawning areas had values ranging from 22.3 to 34.5 percent fines.

Data are included for water quality, streamflow, sediment, turbidity, and temperature for three small streams in the Boise National Forest for calendar years 1976 through 1980. Monitoring of 26 sites believed most likely to contribute sediment along the Warm Lake - Landmark Road Reconstruction Project (reconstruction was done in 1979) reveals that 19 had significant acceleration of sedimentation and three had minor sedimentation. Most of the fine sediments observed in 1979 had been flushed out by 1980 . Two sediment traps below roads in the Roaring Creek Timber Sale collected 100 and 12 cubic feet between 1979 and 1980 , compared with 0.5 cubic feet at an above-road site. Sedimentation was also observed during channel evaluations. The Roaring Creek area had road reconstruction activities in 1979. Preproject monitoring of creeks in the Bad Bear Timber Sale reveals that two of 18 sites are undergoing significant degradation or aggradation, and four sites show minimal sedimentation.

Aggradation, degradation, and pesticide introductions to the South Fork due to cofferdam construction were observed during 1979 monitoring of the hatchery satellite facility. Only minor impacts are noted in preliminary analysis of data from the Bear Creek Timber Sale, logged in 1980. Analyses of data from nine cross-sections of the South Fork show that six have a gain in area (indicating degradation) and three have a loss in area (indicating aggradation), with an average change in area of +3.45 square feet (the time interval involved is not clear). Sediment structure monitoring in Curtis Creek drainage shows 15 cubic feet entrained and 7 cubic feet enroute, for the three below-road structures. Amounts are insignificant for the above-road structures. In Tyndall Creek, one belowroad structure has 6 cubic feet entrained and 4 cubic feet enroute. One above-road structure and three other belowroad structures have no significant sediment entrained or enroute. Water quality data are included in the report.

South Fork Salmon River Monitoring Committee. 1982. Proceedings of the committee meeting; 1982 April 2; Boise, ID. Unpublished report on file at: U.S. Department of Agriculture, Forest Service, Intermountain Research Station, Forestry Sciences Laboratory, Boise, ID. 4 p. plus appendixes.

Results of monitoring efforts are as follows (some data published in references included elsewhere in this bibliography will not be repeated here): Eight monitoring studies (four baseline and four project) conducted by the Boise National Forest in 1981 do not show significant acceleration of erosion or sedimentation, with the exception of the Roaring Creek Timber Sale, where rill and gully erosion from a road fill produced a small amount of sediment. This sediment was trapped behind a retaining structure in a tributary of the South Fork. The 1981 water year is one of low to moderate hydrometeorological stress in the South Fork.

Water quality monitoring by the Payette National Forest on the Secesh, South Fork, and East Fork of the South Fork in 1981 shows no major changes from previous years. Aggradation occurred between 1980 and 1981 on 10 of 16 measured cross-sections of the South Fork, while the other six degraded. All cross-sectional changes are less than a 5 percent difference in area from the previous year, with one possible exception. The report from the Krassel Ranger District indicates a lack of significant impacts in 1981 from land use activities including the Habitat Improvement Sale, the South Fork Road Rehabilitation Project, the Campground Hazard Salvage Sale, the Camp Creek Bridge Project, and the Teapot Timber Sale.

Sampling of aquatic macroinvertebrates was conducted at nine stations on the South Fork in 1981. Six of these correspond to 1980 measurement sites; the other three were added to provide for sampling areas with a greater percentage of fine substrate materials. Samples at the original stations indicate good water quality (as in 1980) and show some slight improvements over the previous year. At the new stations, clean-water species are less abundant and sediment-tolerant species more dominant. 
Overall, the 1981 samples indicate good habitat with no detrimental effects occurring as a result of management activities during the previous year. The report includes data on stream velocities and temperatures at the nine sites in August and October 1981.

Measurements of channel substrate and stream depth at four sites on the South Fork during 1981 show the continuation of a slight but constant trend toward improvement since 1974. It appears that the channel is approaching a new equilibrium point that will be maintained unless a major event occurs.

Redd counts in 1981 on the South Fork, Johnson Creek, and Secesh/Lake Creek were 126, 45, and 53, respectively. These numbers are higher than the counts in 1979 and 1980, but below the 5 -year averages for 1976 through 1980. At the South Fork chinook salmon trap, 400 adults and 124 jacks were captured, with 483,000 green eggs taken from 124 females.

A sediment basin in the Bear Creek Timber Sale accumulated 9.7 cubic yards in the 2 years preceding logging and roading (November 1977 to August 1979), and 5.5 cubic yards in the 2 years of logging and roading (August 1979 to September 1981).

South Fork Salmon River Monitoring Committee. 1983. Proceedings of the committee meeting; 1983 March 8; Boise, ID. Unpublished report on file at: U.S. Department of Agriculture, Forest Service, Intermountain Research Station, Forestry Sciences Laboratory, Boise, ID. 5 unnumbered pages plus appendixes.

Results of 1982 monitoring are as follows (some data published in references included elsewhere in this bibliography will not be repeated here): The 1982 water year was one of moderate to moderately high hydrometeorological stress in the South Fork area. Some failures occurred along the South Fork Road due to heavy runoff, but areas treated in the rehabilitation project show a continued trend toward greater stabilization. Only one mass movement occurred within the rehabilitated areas, a fill failure that delivered 75 cubic yards to the South Fork. Observed impacts are minimal during 1982 activities at the salvage sales, the Secesh-Maverick Creek Timber Sale, and the Camp Creek Bridge Installation. On the Teapot Timber Sale, harvested in 1980 and 1981, harvest units are in good to excellent condition, with good regrowth of herbaceous cover. Roads in the sale area are in good condition. One cut failure of 75 cubic yards occurred, but most of the material is detained behind obstructions. Postsale activities in 1982 take place with no major adverse effects. Data from four soil disturbance transects measured in 1982 show that bulk density had increased an average of 26 percent on compacted disturbed sites in the cutting units. A postsale review of the Teapot Sale results in a list of recommendations for future sales. Overall, the committee feels that the sale has been successful in terms of minimizing impacts through careful planning and supervision.

No major changes in water quality relative to previous years are apparent from samples taken from the Secesh, the South Fork, and the East Fork of the South Fork in 1982. Out of 16 cross-sections of the South Fork in the Payette National Forest measured in 1982, 10 exhibit degradation since 1981, five show aggradation, and one has no change. The highest percentage change in crosssectional area is a 19.7 percent increase at Camp Creek. Included are data for temperatures and velocities measured in 1982 at the nine macroinvertebrate sampling sites.

Redd counts of summer chinook on the South Fork, Johnson Creek, and Secesh-Lake Creek in 1982 were 111, 37 , and 65 , respectively. These are close to the 1981 values. The Secesh-Lake Creek count is above the 5-year average (1977-1981) and the others are lower. Capture at the South Fork trap in 1982 was 502 adult summer chinook salmon and 48 jacks. Green egg take was 648,000 from 147 females.

In 1982, a few cases of minor erosion were observed during informal monitoring of the South Fork Road by Boise National Forest personnel. Minimal sedimentation, with total detention of sediment, occurred on the Bear Creek Timber Sale area. (A total of 7.2 cubic yards of sediment attributable to management activities was delivered to a sediment basin with a source area of 0.32 miles between 1981 and 1982.) Disturbances noted in previous years in the Roaring Creek Timber Sale area have stabilized in 1982. Some gullying occurred at the hatchery satellite facility. Erosion on existing roads in the Bad Bear Timber Sale area showed slight increases in 1982 , but there is no evidence of increased sedimentation in the streams. Stored sediment, attributed to the Warm Lake - Landmark Road Reconstruction Project, was observed in some of the slower moving reaches of Warm Lake Creek. Significant stabilization of the creek occurs in areas directly affected by the project. Analysis of data from cross-sections of the South Fork on the Boise National Forest shows aggradation of five, degradation of two, and no change in one, from 1981 to 1982 . For 1980 to 1982 , five cross-sections have degraded while four have aggraded. The 1982 core sample data from six spawning areas show little change from the 1981 data.

Data on channel substrate, stream depth, and stream width conditions at the Stolle, Poverty, Krassel, and Glory study areas reveal little change since 1974, indicating poor recovery of these areas.

South Fork Salmon River Monitoring Committee. 1984.

Proceedings of the committee meeting; 1984 April 11;

Boise, ID. Unpublished report on file at: U.S. Depart-

ment of Agriculture, Forest Service, Intermountain

Research Station, Forestry Sciences Laboratory, Boise, ID. 16 p. plus appendixes.

Results of 1983 monitoring are as follows (published data reported elsewhere in this bibliography may not be included here): In the South Fork area, hydrometeorological stress during the 1983 water year is moderate.

Chinook salmon and steelhead spawning were concentrated between Poverty Pack Bridge and Miner's Peak Bridge. Steelhead spawning was also concentrated between Miner's Peak Bridge and Knox Bridge. Redd counts of summer chinook from the South Fork, Johnson Creek, and Secesh River-Lake Creek in 1983 were 185, 63, and 98 , respectively, the highest values since 1978 . As measured at the trap, 1983 is the highest year for fish return since operation began in 1980. Trapped fish included 937 adults. Eggs taken from 180 females totaled 
750,634. Tagged fish had an average travel time of 25.6 days from Lower Granite Dam to the trap.

The percentage of fines on the surface of key spawning areas is unchanged in 1983. This and other measured variables, such as stream width and depth, indicate uniform conditions since 1974. Cross-section data (1978 to 1983) show that the upper section of the South Fork had 1.8 percent bed deposition, the middle section had 1.8 percent bed erosion, and the lower part had 4.8 percent bed erosion. The data reflect the major changes, approaching geologic proportions, occurring at the Oxbow area due to the breach of the Oxbow. The committee notes that changes in bottom materials below the Oxbow breach should not be attributed to management activities, and that impacts might be severe.

The 1982 to 1983 trend in nine cross-sections of the South Fork measured by the Boise National Forest is one of slight aggradation, with all sections showing less than 5 percent change in area. Because these are in reaches with relatively slow velocities, the aggraded material may have been flushed out of upstream reaches during high flows in 1982 and 1983. A few small slides were observed on the South Fork Road in 1983, but all of the eroded material was retained on the road. Presale monitoring of the Bad Bear Timber Sale area shows some rill and gully erosion on existing roads, probably due to bypassing of waterbars by flows. No sediment delivery to streams has occurred. Gullying near the holding ponds and two small cutslope slumps happened at the hatchery satellite facility in 1983. Revegetation of cutslopes and other disturbed areas is progressing well. In the Roaring Creek Timber Sale area, two sediment traps with source areas of 60 and 40 acres have impounded about 10 and 4 cubic yards, respectively, in 4 and 3 years. Both of these traps have roads in their source areas, and the first has a log landing as well. Revegetation problems are noted on the landing and a few road reaches. The committee concludes that management activities being monitored in the South Fork drainage by the Boise National Forest during the preceding years have not had any unacceptable impacts. Two years of aboveaverage precipitation have enhanced revegetation rather than accelerated erosion.

On the Payette National Forest, measurements of 16 cross-sections of the South Fork indicate aggradation at nine and degradation at seven for 1982 to 1983 . The Camp Creek site, which had been undergoing scour for the three previous years, had 19.35 percent aggradation. Changes there are attributed to the Oxbow breach and an upstream channel constriction. From 1978 to 1983,12 stations show scour and four show fill. Measurements of stream temperature and velocity taken in 1983 at six South Fork sites are tabulated. No significant differences in percentage of surface fines are detected in Lick Creek above and below the area affected by the Secesh-Maverick Creek Timber Sale. Percentage of fines is not a reliable indicator of the quality of fish habitat. Cobble embeddedness and accumulated fines within spawning gravels are the critical factors in fish response. Techniques are being developed to measure these variables. Since implementation of the Land Management Plan, fish habitat appears to be stable upstream of the Oxbow area, with flushing of sediments in the downstream reaches. Fish habitat is generally not of high quality in the planning unit.
Minimal impacts were noted during 1983 visits to the Habitat Improvement Timber Sale and the salvage sales. Both the roads and the cutting units in the Teapot Timber Sale are revegetating and generating little sediment. Objectives of the South Fork Road Rehabilitation Project appear to be met in most cases by 1983 . The road prism has become the major source of accelerated sedimentation, with rill and gully erosion common during rain and snowmelt events. For both the Secesh and Rainbow Timber Sales, 1983 was the first year of activity, and both sales are considered successful in terms of minimizing impacts. The Rainbow Sale had been designed with a maximum effort to reduce impacts. The effort included the use of helicopters.

South Fork Salmon River Monitoring Committee. 1985. Proceedings of the committee meeting; 1985 April 9; Boise, ID. Unpublished report on file at: U.S. Department of Agriculture, Forest Service, Intermountain Research Station, Forestry Sciences Laboratory, Boise, ID. $12 \mathrm{p}$. plus appendixes.

The following results of 1984 monitoring efforts are presented (data published in reports included elsewhere in this bibliography may not be included here): The 1984 water year was one of moderate climatic stress, with some localized high stress events, in the South Fork. High intensity rainstorms generated floods on Blackmare Creek (where 150 to 400 cubic yards of sediment were deposited in the stream) and on Rice Creek (where 1,500 to 9,000 cubic yards were deposited, and a tributary channel was scoured). The impacts in Rice Creek are not associated with any land management activities.

Redd counts of summer chinook in the South Fork, Johnson Creek, and Secesh River-Lake Creek were 165, 17 , and 21 , respectively, in 1984 . Wild runs of salmon appeared to be in fairly poor condition, but this is not necessarily indicative of a trend. In 1984, 934 adults and 595 jacks were trapped, and 1,600,000 eggs were taken. The numbers of returning adults trapped increased between 1980 and 1984.

A steelhead study in the South Fork drainage began in 1984. Preliminary results of the first year's data show 407 redds, 70 percent of which were in the main stem. Survival from egg to fry at Poverty, where several redds were capped, was only 8 percent. Heavy embeddedness of some rearing areas is apparent.

Project monitoring efforts by the Boise National Forest in 1984 reveal little in the way of new problems. Despite 3 consecutive years of above average precipitation and streamflow, no unacceptable impacts have been observed from any of the monitored activities.

Project monitoring continued in the Payette National Forest in 1984. Conditions are good at the Secesh Timber Sale (ground-based) and the Rainbow Timber Sale (helicopter). Some drainage problems, resulting in sediment delivery of 10 cubic yards to Homedale Creek, occur on roads in the Teapot Timber Sale area. The South Fork Road continues to exhibit rill and gully formation during rain and snowmelt periods. This is due largely to rutting, which concentrates surface runoff. A dust abatement material applied to the road in the Poverty Burn area reduced rilling during storms and controlled the dust. 
However, it also produced a slippery surface during storms, and some rutting occurred.

Baseline hydrologic monitoring continued on the Boise and Payette National Forests in 1984. The South Fork cross-sections on the Boise Forest show no strong trend. Most of the South Fork cross-sections measured on the Payette Forest have a change in area of less than 2 percent for 1983 to 1984 . The trend for the Payette sample appears to be one of scour for 1978 to 1984 , with the exception of the Lower Oxbow site, which is filling due to the Oxbow breach. However, an analysis of variance shows no significant change in channel elevation at any of the Payette sites since 1977. Elevation data are considered more meaningful than cross-sectional area data in assessing streambed changes. Good long-term streamflow data are available for the South Fork, and frequency distributions have been developed for annual and peak flows. The water quality samples taken from the Secesh, the South Fork, and the East Fork of the South Fork in 1984 show elevations in some of the values. These could possibly be the result of errors in analysis rather than real changes. Other baseline hydrologic monitoring reveals a small mass failure on the Two Bit - Six Bit Road (retained on the road) and a small to medium blowout of a draw on Kline Mountain.

Baseline fish habitat monitoring conducted by the Payette National Forest in 1984 includes studies of macroinvertebrates, cobble embeddedness, and core samples. The macroinvertebrate species monitored were chosen because of their sensitivity to sedimentation. Densities of the sensitive species do not increase with an increase in fine sediment. These results concur with published studies that show no change in densities until a threshhold of 30 percent fines, or two-third cobble embeddedness, is exceeded. Embeddedness was high in rearing areas of the main stem and moderate in the Secesh and the East Fork South Fork. No change in embeddedness is observed in Blackmare Creek following the blowout. Regression analyses of percentage of fines for 1975 through 1984 show decreasing trends at Dollar, Poverty, Oxbow, and Glory. For all these except Glory, the trend is less pronounced in the later years (1982 to 1984). Stolle shows no significant difference from a zero slope, while Johnson Creek shows an increasing trend. There is an increase in fines at the Stolle site following the Rice Creek flood, although the substrate appears to be clean.

South Fork Salmon River Monitoring Committee. 1986. Proceedings of the committee meeting; 1986 April 21; Boise, ID. Unpublished report on file at: U.S. Department of Agriculture, Forest Service, Intermountain Research Station, Forestry Sciences Laboratory, Boise, ID. 3 p. plus appendixes.

Results of 1985 monitoring are as follows (data in references included elsewhere in this bibliography may not be reported here): Water year 1985 is one of low to moderate hydrometeorological stress in the South Fork drainage, although high-intensity storms impact some isolated areas.

Fish studies conducted by the Idaho Department of Fish and Game show counts up in 1985 for all populations. Summer chinook redd counts for the South Fork, Johnson Creek, and Secesh River-Lake Creek were 323, 75, and
105 , respectively. These values are more than twice the 5-year averages for 1980 through 1984. The habitat is still underseeded. Trapping operations captured 1,409 adults and 828 jacks, and 2,073,546 eggs were taken. Densities of steelhead trout, cutthroat trout, bull trout, and chinook salmon are all significantly related to embeddedness values. The findings indicate that sediment limits rearing populations of resident and anadromous fish in the South Fork.

Regression analyses for core sampling data collected by the Boise National Forest at six spawning areas show trends not significantly different from a zero slope at Stolle, Dollar, Poverty, and Oxbow. The latter three areas have negative trends for the previous years. Glory exhibits a negative trend (indicating decreasing fine sediments), while the trend at Johnson Creek is positive (indicating an increase in fine sediments). Observations at Rice Creek show significant movements of bed and suspended loads. Suspended sediments from Rice Creek are apparent in the South Fork below the confluence of the streams but are not observed at the Stolle spawning area. Bedload sediments are stored in the Rice Creek channel. Two road stabilization projects and two bank stabilization projects carried out in 1985 are expected to reduce sediment deposits into the South Fork system.

Analysis of variance results for the Boise National Forest core sample data show no detectable time trend at Stolle (although the means are significantly different over time). However, Poverty, Glory, Oxbow, and Johnson Creek all show time trends. The data confirm that percentage of fines is increasing at most sites.

Surveys of the South Fork cross-sections on the Boise National Forest show a slight decrease in area at Lower and Upper Stolle, possibly in response to the Rice Creek flood of August 1984. A cross-section of Rice Creek shows a 20 percent decrease in area from 1984 to 1985 due to sand deposition. Other 1985 monitoring activities conducted by the Boise National Forest reveal minimal adverse management impacts.

Only three of 16 cross-sections measured by the Payette National Forest showed changes greater than 3 percent between 1984 and 1985 . The only site that shows an area change in excess of 3 percent since implementation of the South Fork Management Plan (1978 to 1985) is Lower Oxbow. Changes there are attributed to the Oxbow breach. Chloride values of the 1985 water quality samples from the South Fork, the Secesh, and the East Fork of the South Fork are low, in contrast to the high values reported in 1984. None of the values for any of the measured factors are unusually high.

Two sediment traps on the inside ditch of steep sections of the South Fork Road in the Payette National Forest were effective in collecting considerable amounts of sediment, while one on a road section with a lower gradient caught little sediment. Erosion from the road prism due to surface runoff continues to be the greatest problem associated with the road. The road constitutes a major source (if not the major source) of sediment deposits into the South Fork. Other monitoring conducted by the Payette National Forest in 1985, including monitoring of the Secesh Timber Sale, reveals few problems. 
Stowell, Rick; Espinosa, Al; Bjornn, Ted C.; Platts, William S.; Burns, Dave C.; Irving, John S. 1983. Guide for predicting salmonid response to sediment yields in Idaho batholith watersheds. Ogden, UT: U.S. Department of Agriculture, Forest Service, Northern and Intermountain Regions. $95 \mathrm{p}$.

As an aid to the forest planning process, researchers sought a standardized method for predicting the effects of sediment on stream habitat and fish populations within the Idaho batholith. This series of models is based primarily upon relationships developed in laboratory studies. Using watershed estimates of sediment yield over natural yield, this report offers equations predicting channel embeddedness, percentage of fines by depth, and changes in fish population. The user may then assess the impacts upon fishery habitat and create management-mitigation options. The authors feel that the model could be revised and updated for application to other geographic regions. The South Fork Salmon River is used as an example of watershed recovery under an intensive timber management program.

Tappel, Paul D.; Bjornn, Ted C. 1983. A new method of relating size of spawning gravel to salmonid embryo survival. North American Journal of Fisheries Management. 3: 123-135.

A new method for describing the size composition of salmonid spawning gravel has been developed from stream gravel samples of the South Fork Salmon River, ID, and the Clearwater River, WA. Distributions of particle sizes less than $25.4 \mathrm{~mm}$ consistently plot as straight lines on log-probability paper. Because of the lognormal distribution of the particle sizes in this range, the size composition of material smaller than $25.4 \mathrm{~mm}$ is closely approximated by two points on a regression of cumulative particle size distribution. The two size classes that best reflect the composition of the spawning gravel size are the percentage of the substrate smaller than $9.50 \mathrm{~mm}$ and the percentage smaller than $0.85 \mathrm{~mm}$. Laboratory tests focus on chinook and steelhead survival as compared to substrate composition. (Adapted from authors' abstract.)

Thompson, Richard A.; Skabelund, Paul H.; Kulesza, Norbert C. 1973. Soil-hydrologic reconnaissance, McCall Ranger District, Payette National Forest. McCall, ID: U.S. Department of Agriculture, Forest Service, Intermountain Region, Payette National Forest. 227 p.

This report follows the same format, and uses much of the information from, previously published soil-hydrologic reconnaissance reports from the Cascade and Krassel Ranger Districts (USDA FS 1969, 1970). Like those reports, it also draws upon the South Fork Salmon River Special Survey, Soils and Hydrology Report (Arnold and Lundeen 1968).

Fifty-five landtypes (the basic unit of the report) are identified within the District and are placed into four geomorphic groups, the same as those described for the Cascade District report. Strongly glaciated lands make up 35.9 percent of the area and include 23 landtypes. Periglaciated lands include six landtypes and account for 18.9 percent of the area. There are 15 landtypes within the fluvial lands, which constitute 32.8 percent of the area.
Depositional lands include 11 landtypes and 12.1 percent of the area.

Torquemada, R. J.; Platts, W. S. 1983. Poverty spawning area - South Fork Salmon River, Idaho; Progress Report 1, 1977-1982. Unpublished report on file at: U.S. Department of Agriculture, Forest Service, Intermountain Research Station, Forestry Sciences Laboratory, Boise, ID. $36 \mathrm{p}$.

Substrate conditions in the Poverty spawning area over a 6-year period indicate that stream channel surface substrates have stabilized at levels that provide for successful spawning. Subsurface fines show a slower rate of improvement and may limit salmonid production. Stream temperature data are included. Monitoring of the Poverty spawning site was terminated in 1983 , so subsequent reports have not been written.

Ulliman, Joseph J.; Singh, Harnek; Megahan, Walter. 1983. Remote sensing detection for planning on the Salmon River. In: Proceedings, 1982 convention of the Society of American Foresters; 1982 September 19-22; Cincinatti, OH. Publication 83-04. Washington, DC: Society of American Foresters: 133-137.

The researchers have developed an aerial photo interpretation scheme for detecting riverbottom surface sediments and for planimetrically mapping various size classes using historical aerial photography. At three sites on the South Fork of the Salmon River, sand, gravel, cobble, rubble, and boulders are mapped on small-scale aerial photos of $1946,1947,1952,1965$, and 1972, and on large scale aerial photos of $1965,1972,1976$, and 1979. Crosssection profiles are also measured from the photos with a limited degree of accuracy. Both aerial photo and ground data are statistically analyzed and used to display time trend curves for the sediments. A computer mapping program is then used to enhance the graphic display of the data. Average error of the aerial photo-interpreted data ranges between 10 and 23 percent depending on which of two types of ground data are used. (Adapted from authors' abstract.)

U.S. Department of Agriculture, Forest Service. 1962.

South Fork Salmon River and tributaries stream habitat survey. Boise, ID: Boise National Forest. 31 p.

Crews surveyed 25 miles of the main stem South Fork Salmon River and 40 miles of its tributarys streams with respect to fishery habitat. Variables measured include pool size, large surface substrates, bank vegetation, depth, instream vegetation, velocity, and bank stability.

U.S. Department of Agriculture, Forest Service. 1969. Soil-hydrologic reconnaissance of Cascade Ranger District, Boise National Forest. Boise, ID: U.S. Department of Agriculture, Forest Service, Intermountain Region, Boise National Forest. 150 p.

This inventory of soil and water resources of the District, intended to provide information for multiple-use planning. The report draws heavily on the South Fork Salmon River Special Survey, Soils and Hydrology (Arnold and Lundeen 1968). The South Fork Survey area includes about two-thirds of the District. 
The basic unit of the report is the landtype. Researchers identify 35 landtypes on the District and put them into four broader categories of geomorphic groups. Each landtype is described by location, management zone, extent, topography, geomorphic features, bedrock characteristics, vegetation, soils, and management qualities. The report also includes a table of landtype characteristics, hydrologic qualities, erosion potential, and stability hazards.

The first geomorphic group, strongly glaciated lands, includes 11 landtypes and comprises 28.4 percent of the area. These lands occur in the headlands of most of the drainage tributaries of the South Fork Salmon River. Strongly glaciated lands are the chief water producers and have the greatest snow accumulations in the area. They are considered to be relatively stable for road construction purposes, although construction of road cuts in the hard unweathered rock can be difficult. These lands are the poorest timber producers.

The second geomorphic group, weakly glaciated uplands, includes three landtypes and comprises 15 percent of the area. Mass wasting is the dominant natural erosion process. Hydrologic and engineering characteristics are generally favorable.

Fluvial lands, the third geomorphic group, includes 13 landtypes and comprises 47.9 percent of the area. These lands are characterized by moderately well to wellweathered quartz monzonite bedrock (which spalls upon exposure) and steep slopes.

The final geomorphic group is depositional lands, with eight landtypes and 8.7 percent of the area. These lands are important in the storage of water from the higher elevations. Road construction potential is excellent, with a few precautions.

\section{U.S. Department of Agriculture, Forest Service. 1970.} Soil-hydrologic reconnaissance, Krassel Ranger District, Payette National Forest. McCall, ID: U.S. Department of Agriculture, Forest Service, Intermountain Region, Payette National Forest. 148 p.

This report has the same objectives and format as the soil-hydrologic reconnaissance report for the Cascade Ranger District (USDA FS 1969). The content is also largely the same. This report also draws heavily on the South Fork Salmon River Special Survey, Soils and Hydrology Report (Arnold and Lundeen 1968), as well as the Hydrologic Analysis Report of the Zena Creek logging study area (Jensen and Finn 1966). The District is entirely in the South Fork Salmon River drainage.

The basic unit of the report is the landtype. Researchers identify 35 landtypes on the District and put these into four geomorphic groups. The geomorphic groups are the same as those described in the Cascade District report; therefore, the information will not be repeated here. The geomorphic groups of strongly glaciated lands, weakly glaciated uplands, fluvial lands, and depositional lands include 11, 3, 13, and 8 landtypes, respectively, and make up respective areas of $36.4,6.1,49.0$, and 8.5 percent of the total area.

\section{U.S. Department of Agriculture, Forest Service. 1985.}

South Fork of the Salmon River appendix for the

Payette and Boise National Forests proposed land and resource management plans. Ogden, UT: U.S. Department of Agriculture, Forest Service, Intermountain Region. $151 \mathrm{p}$.

This overview of the South Fork Salmon River and the management direction and activities for the entire drainage includes reviews and summaries for: (1) location, topography, fish, wildlife, and wilderness; (2) geographic development, development history, and land management plans for the area; (3) anadromous fish, environmental consequences to fish habitat, and fish/sediment relations from 1945 to present; (4) relative impacts of old vs. new logging techniques; and (5) resource outputs, activities, costs, and benefits.

The bulk of the appendix is material highlighting the proposed and probable management practices, activity schedules, and monitoring plans established by the Boise and Payette National Forests as these affect the South Fork Salmon River drainage. Drawn from the 1985 draft land management and resource plans of the two Forests, this information is presented by management area.

Welsh, Thomas L. 1969. South Fork of the Salmon River weir counts, harvest and escapement study, 1968. Boise, ID: Idaho Department of Fish and Game. $15 \mathrm{p}$.

Summer run chinook salmon were counted on the South Fork Salmon River at a temporary weir from 1964 to 1968. Counts range from a high of 3,300 in 1966 to a low of 1,500 in 1968. Salmon harvest ranges from a high of about 4,000 fish in 1960 to a low of 91 in 1968. Angling pressure falls with reduced harvest from a high of 12,500 angler days in 1962 to 400 angler days in 1968. Sex and age composition data are included.

Wendt, G. E.; Thompson, R. A. 1978. Soil inventory key to South Fork Salmon River Land Management Plan. In: Forest soils and land use: Proceedings, fifth North American forest soils conference; 1978 August; Fort Collins, CO. Fort Collins, CO: Colorado State University, Department of Forest and Wood Sciences: 214-224.

Determining a suitable mix of resource products is complicated by steep slopes and erosive soils in the South Fork of the Salmon River Planning Unit. The initial environmental statement and land management plan are appealed, resulting in specific direction for a new land management plan and environmental statement that quantify effects of management activities on the anadromous fish habitat.

Soil mapping units are used as the initial basis for development of analysis units, management areas, and management units. Soil mapping units, along with research data, are used to develop quantified average sediment estimates for each analysis unit. In addition, they are used as a basis for estimating quantified impacts from various management activities and for allocating areas of land to various resource uses.

Using the quantified values, a computer program generates a number of alternatives and displays the impact of each relative to the tolerable levels of sediment established for the anadromous fish spawning areas.

The blending of numerous talents and resources produces an environmental statement and land management 
plan with quantified resource information that visibly displays the land management decision-making process. (Adapted from authors' summary.)

Williams, Ted. 1981. Keeper of the rivers. Gray's Sporting Journal. South Hamilton, MA: Gray's Sporting Journal, Inc.; 6(1): 83-91.

This article reviews the current condition of several rivers and their watersheds as impacted by the Forest Service and forestry practices. It provides a history of the degradation of the South Fork Salmon River and its fisheries.

Zena Creek Logging Study Committee. 1963. Minutes of the committee meeting; 1963 June 4-5. Unpublished report on file at: U.S. Department of Agriculture, Forest Service, Intermountain Region, Payette National Forest, McCall, ID. 5 p. (p. 1-2).

Sediment yields from the Tailholt drainage for 1961 , 1962 , and 1963 are $8.9,14.8$, and 15.2 tons per square mile, respectively. Suspended sediment yields are low, even during periods of high flow such as the 1962 fall rains and the 1963 spring runoff, which have measured discharges of 9.0 and 7.0 cubic feet per second, respectively. Sediment yields from the Circle End watershed are lower than those from Tailholt. Circle End has a measured yield of 10 tons per square mile in 1963, the first full year of measurement. Circle End watershed has granitic soils with a lower clay content and greater ground cover than the Tailholt watershed. 

Seyedbagheri, Kathleen A.; McHenry, Michael L.; Platts, William S. 1987. An annotated bibliography of the hydrology and fishery studies of the South Fork Salmon River. Gen. Tech. Rep. INT-235. Ogden, UT: U.S. Department of Agriculture, Forest Service, Intermountain Research Station. 27 p.

A brief summary of the land management history of the South Fork Salmon River (Idaho) watershed includes citations and annotations of published and unpublished reports of fishery and hydrology studies conducted in the South Fork drainage for 1960 to 1986.

KEYWORDS: aquatic habitat, sedimentation, erosion, anadromous fish, logging, forest road construction, Idaho batholith 


\section{INTERMOUNTAIN RESEARCH STATION}

The Intermountain Research Station provides scientific knowledge and technology to improve management, protection, and use of the forests and rangelands of the Intermountain West. Research is designed to meet the needs of National Forest managers, Federal and State agencies, industry, academic institutions, public and private organizations, and individuals. Results of research are made available through publications, symposia, workshops, training sessions, and personal contacts.

The Intermountain Research Station territory includes Montana, Idaho, Utah, Nevada, and western Wyoming. Eighty-five percent of the lands in the Station area, about 231 million acres, are classified as forest or rangeland. They include grasslands, deserts, shrublands, alpine areas, and forests. They provide fiber for forest industries, minerals and fossil fuels for energy and industrial development, water for domestic and industrial consumption, forage for livestock and wildlife, and recreation opportunities for millions of visitors.

Several Station units conduct research in additional western States, or have missions that are national or international in scope.

Station laboratories are located in:

Boise, Idaho

Bozeman, Montana (in cooperation with Montana State University)

Logan, Utah (in cooperation with Utah State University)

Missoula, Montana (in cooperation with the University of Montana)

Moscow, Idaho (in cooperation with the University of Idaho)

Ogden, Utah

Provo, Utah (in cooperation with Brigham Young University)

Reno, Nevada (in cooperation with the University of Nevada)

USDA policy prohibits discrimination because of race, color, national origin, sex, age, religion, or handicapping condition. Any person who believes he or she has been discriminated against in any USDA-related activity should immediately contact the Secretary of Agriculture, Washington, DC 20250. 